\title{
Evaluating the Trade Effect of Developing Regional Trade Agreements: a Semi-parametric Approach
}

\author{
Souleymane Coulibaly \\ The World Bank
}

\begin{abstract}
Many recent papers have pointed to ambiguous trade effects of developing regional trade agreements, calling for a reassessment of their economic merits. This paper focuses on 22 RTAs involving mostly developing countries and covering all the continents and use trade flows over the period 1962-2006. It proposes a two-step estimation approach to assess their trade impact: first estimate a gravity equation excluding the RTA variables, and then use the trade residuals estimated to run a kernel regression for each of the RTAs. This approach allows capturing the non-monotonic trade effects of the RTAs over time while imposing minimal structure on the model, and is flexible enough to be extended to any new RTA. As existing RTAs are deepened and new ones are being negotiated, ensuring that trade creation dominates trade diversion will be essential, particularly in the post-crisis world where resources will be limited for all countries.
\end{abstract}

-JEL Classification: F11, F15, O50

- Key Words: regional trade agreement, kernel regression, two-step estimation, trade impact, gravity model

\footnotetext{
*Souleymane Coulibaly: The World Bank, 1818 H Street NW, 20433 Washington DC, USA, MSN: H4402, Tel: +1 202473 9845, e-mail: scoulibaly2@worldbank.org.

*The findings, interpretations, and conclusions expressed in this paper are entirely those of the author. They do not necessarily represent the view of the World Bank, its Executive Directors, or the countries they represent.

@2009-Center for International Economics, Sejong Institution, Sejong University, All Rights Reserved.
} 


\section{Introduction}

At the beginning of the 1990s, the WTO was reporting 40 regional and bilateral agreements. Nineteen years later, this number has grown to more than 200, most of the agreements being signed by developing countries. The WTO General Council established the Committee on Regional Trade Agreements to examine individual agreements and consider their systemic implications on the multilateral trading system. The World Bank has engaged a research program on regionalism and development which led to the publication of a Policy Research Report offering a set of ideas to better manage regionalism worldwide. ${ }^{1}$ The UNCTAD also funded a study on regionalism and Africa's development which proposed an intensification of Africa's efforts on regional and Sub-regional economic integration. ${ }^{2}$ With the multilateral trade agenda in a stalemate since the failure of the Cancun negotiation in 2003, more and more regional and bilateral trade agreements are to be expected.

This new interest in regionalism has also inspired researchers to prospect more rigorous approaches to estimate the trade impact of these regional agreements. Since Aitken (1973) who estimated the trade creation and trade diversion effects of the European Community by including some Regional Trade Agreement (RTA henceforth) dummy variables in a gravity model, this model has been the workhorse used by trade economists to analyze the trade impact of RTAs. Baier and Bergstrand (2002), Anderson and Van Wincoop (2003) and Feenstra (2004) among others have presented a rigorous theoretical derivation of the gravity model and its extension to include RTA variables. Many papers have discussed the econometric tools used to estimate gravity equations. Matyas (1997), Matyas (1998), and Egger (2000) among others showed that a panel approach yields better results than a cross-section approach since it allows capturing the overall business cycle phenomenon faced by the trading partners and helps to disentangle timeinvariant country-specific effects. They argue that these country-specific effects should be assumed fixed if the sample only includes a predetermined subset of countries and random if a larger sample including any country at random is used. Martinez-Zarzoso and Nowak-Lehmann (2003), Egger and Pfaffermayr (2003), and Cheng and Wall (2005) among others show that a panel specification including exporter, importer and time effects is only a restricted version of a more general model allowing for country-pair heterogeneity. Carrere (2006) suggests using a

${ }^{1}$ Maurice Schiff and Alan Winters (2003).

${ }^{2}$ UNCTAD (2000). 
Hausman-Taylor specification including three RTA dummy variables covering countries' exports, imports and intra-regional trade flows to properly estimate the trade effect of RTAs. Baldwin and Taglioni (2006) suggests that the best approach is to use unidirectional trade flows and include country-pair and time dummy variables, or country-time dummy variables to correct for the inadequate deflation of the trade flows and partially correct for omission of a multi-lateral resistance factor.

Certainly, many ongoing papers are still trying to propose the most relevant econometric approach to estimate the trade impact of RTAs. The more sophisticated these approaches and the larger the set of RTAs to be evaluated, the more challenging it is to have a single specification encompassing all the existing RTAs. For instance, we tried to use the Hausman-Taylor specification proposed by Carrere (2006) including three RTA variables for the 22 RTAs we identified as relevant but we failed because it required more computation capacity than what our quite powerful computer were able to provide. With these capacity limitations, it will be more and more difficult to include in a single regression all the RTAs existing and to be signed, hence a lack of common ground that allows comparing the trade impact of these RTAs. To provide such common ground to assess RTAs' trade impact, this paper suggests a two-step estimation approach combining the estimation of a gravity equation with a kernel regression. We first propose for each RTA three variables (import, export and intra-trade specific) based on the count of the number of years each member has participated, hence helping to capture the cumulative effect of being an RTA member over time. ${ }^{3}$ We then use the fixed effects specification proposed by Baldwin and Taglioni (2006) and the random effects specifications proposed by Carrere (2006) to estimate a gravity equation excluding the RTA variables. Our choice of considering both approaches (random and fixed effects) is to move beyond the random vs. fixed effects debate (see brief literature review above on estimation techniques) and propose a practical way to confidently estimate the trade impact of any RTA irrespective of the initial choice of a random or a fixed effect approach. The trade residuals of these two regressions are then extracted and used as dependent variables in a kernel regression for each of the RTA-variables of 22 well-known RTAs. ${ }^{4}$ In addition to the practicality of this

\footnotetext{
${ }^{3}$ This approach is inspired by Freund and McLaren (1999) who introduced an alternative way of looking at RTAs trade effect by focusing on the dynamic of trade orientation when a country joins a regional trade agreement and over the number of years of membership.

${ }^{4}$ Appendix 1 describes these RTAs.
} 
semi-parametric approach, the kernel regression captures the non-linearity of the trade impact of RTAs by imposing a minimal specification structure.

The trade impacts estimated by the fixed effects specifications appear to be slightly higher than those obtained with the random effects specifications, and almost all these RTAs appear to have at least induced more intra-RTA trade, except for BIMSTEC, CACM, CEMAC, EEU and GCC. The remainder of the paper first review the RTAs considered in section II, and then describes the semi-parametric estimation approach in section III. Section IV presents the empirical analysis and discusses the trade impacts estimated for these RTAs. Section V concludes the paper.

\section{Review of the RTAs}

Of the 218 regional and bilateral trade agreements reported to the WTO, 118 are bilateral agreements; 54 are agreements between a country or a regional grouping with another regional grouping, and 56 are "pure" regional trade agreements. In this paper, we focus on 22 of these regional trade agreements based on their member commitment to the regional trade agenda. Four of them involve East and South Asian and Pacific countries: the ASEAN Free Trade Agreement (AFTA, entered into force in 1992), the South Asian Preferential Trade Agreement (SAPTA, entered into force in 1993), the Bangladesh India Myanmar Sri Lanka Thailand Economic Cooperation (BIMSTEC, entered into force in 1997), and the South Pacific Regional Trade and Economic Cooperation Agreement (SPARTECA, entered into force in 1981). Six of them comprise Western Hemisphere countries: the Central American Common Market (CACM, entered into force in 1990) ${ }^{5}$, the Andean Community (CAN, entered into force in 1988) ${ }^{6}$, the Caribbean Community and Common Market (CARICOM, entered into force in $1973)^{7}$, the Group of Three (GOT, entered into force in 1995), the Common Market of the Southern Cone (MERCOSUR, entered into force in 1991), and the North America Free Trade Agreement (NAFTA, entered into force in 1994). Six of them have been signed by Sub-Saharan African countries: the Economic

\footnotetext{
${ }^{5}$ In fact, the CACM was initially created in 1958 but had suffered many downturns until its revival in 1990 with an increased cooperation with the EU.

${ }^{6}$ Note that in 2006, Venezuela withdrew from the CAN complaining about the bilateral free trade agreements between Colombia and Peru with the US.

${ }^{7}$ The CARICOM replaced the CARIFTA (Caribbean Free trade Area) which existed from 1965 to 1973.
} 
Community of West African States (ECOWAS, entered into force in 1975) ${ }^{8}$, the Southern African Development Community (SADC, entered into force in 1992), the Economic and Monetary Community of Central Africa (CEMAC, entered into force in 1999) ${ }^{9}$, the East African Community (EAC, entered into force in 2000) ${ }^{10}$, the Southern Africa Customs Union (SACU, entered into force in 1970), and the West Africa Economic and Monetary Union (WAEMU, entered into force in 1994) ${ }^{11}$. Three of them regroup Middle East and North Africa countries: the Arab Free Trade Agreement (ArFTA, entered into force in 1997), the Arab Maghreb Union (AMU, entered into force in 1989), and the Gulf Cooperation Council $\left(\mathrm{GCC}\right.$, entered into force in 2003) ${ }^{12}$. Finally, three of them involve European and Central Asian countries: the European Union (EU, entered into force in 1957) ${ }^{13}$, the Commonwealth of Independent States (CIS, entered into force in 1991), and the Eurasian Economic Union (EEU, entered into force in 2000). See the membership of all these regional trade agreements in Appendix.

Existing studies evaluating the trade impact of RTAs are selective in the agreements included. For instance, Gosh and Yamarik (2004) include twelve of them: AFTA, ANZCERTA, APEC, CACM, CAN, CARICOM, EEA, EFTA, EU, LAIA, MERCOSUR, and NAFTA. ${ }^{14}$ Carrere (2006) considers only seven: AFTA, CACM, CAN, EU, LAIA, MERCOSUR, and NAFTA. Baier, Bergstrand and Vidal (2006) focus also on seven: CACM, CAEIA, CARIFTA, CARICOM, GOT, MERCOSUR and NAFTA. ${ }^{15}$ Furthermore, many studies of the trade impacts of developing RTAs come to different conclusions. For instance, AFTA, LAIA ${ }^{16}$ and MERCOSUR appear to have been net trade creating in some studies and net trade diverting in others (Table 1). These studies use different estimation methods,

\footnotetext{
${ }^{8}$ Mauritania withdrew from ECOWAS in 1999 after a military coup. Since then, the country has been informally involved in economic and political cooperation with the other ECOWAS countries.

${ }^{9}$ In fact, the CEMAC has existed since 1964 as a currency union but were less involved in regional trade until 1999 when the members decided to form a Customs Union.

${ }^{10}$ The first initiative to have an Eastern African Cooperation collapsed in 1973 upon political and economic disagreements between Kenya, Tanzania and Uganda.

${ }^{11}$ The WAEMU has existed since 1964 as a currency union, but became an economic and monetary union in 1994 with a stronger commitment of its members to economic integration.

${ }^{12}$ Council has existed since 1981, but became a customs union in 2003.

${ }^{13}$ The EC has experienced 5 waves of enlargements since its creation in 1957, the largest being in 2004 with 10 new members and the most recent being in 2007 with Bulgaria and Romania.

${ }^{14}$ APEC stands for Asia-Pacific Economic Cooperation; EEA stands for European Economic Area; EFTA stands for European Free Trade Area.

${ }^{15}$ CAIEA stands for Central America Economic Integration Agreement. Baier, Bergstrand and Vidal (2006) focus more on bilateral free trade agreements.

${ }^{16}$ LAIA: Latin America Integration Agreement.
} 
Table 1. Contradicting Trade Impact of Some Developing RTAs

\begin{tabular}{ccc}
\hline & Net Trade Creation & Net Trade Diversion \\
\hline AFTA & Carrère (2004) & Dee \& Gali (2003) \\
& Elliott \& Ikemoto (2004) & Soloaga \& Winters (2000) \\
& Gosh \& Yamarik (2004) & \\
Cernat (2001) & Carrère (2004) \\
& Dee \& Gali (2003) & Soloaga \& Winters (2000) \\
GERCOSUR & Gosh \& Yamarik (2004) & Carrère (2004) \\
& Soloaga \& Winters (2000) & Dee \& Gali (2003) \\
& Gosh \& Yamarik (2004) & Krueger (1999) \\
\hline
\end{tabular}

different databases and different dynamic specifications to measure trade impacts, and they focus on the number of years these RTAs have existed to estimate their trade impact. This paper expands the list of RTAs ever included in a single study to 22 and provides an estimation approach making it easier to extend the analysis to any new regional agreement.

\section{Semi-parametric Estimation of the Trade Impact of RTAs}

To properly measure the trade effect of an RTA, we focus on the export flows of its trading partners in a global framework as described in Figure 1. The subset RTA comprises the member countries of the RTA under consideration and the subset ROW represents all the remaining countries in the world. This helps to define the set of three variables characterizing any RTA.

Figure 1. Geography of World Trade Flows

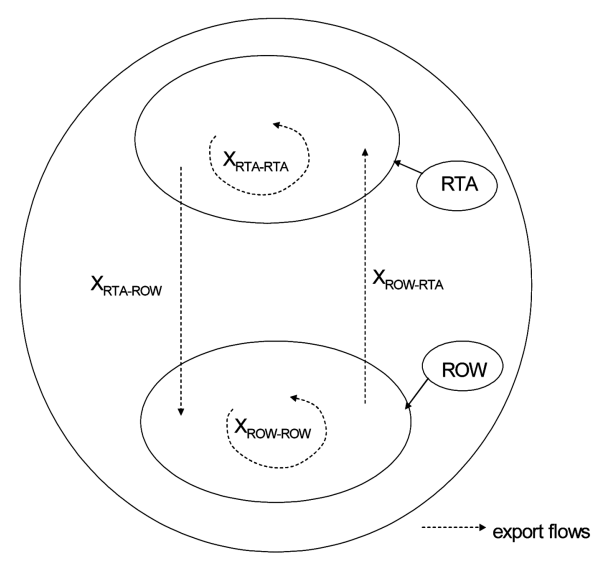


Table 2. Number of Years of Participation of AFTA Members

\begin{tabular}{cccc}
\hline & Years of participation: $Y P(i, t)$ & \\
\hline & 2000 & 2005 & Year: $t$ \\
\hline Brunei & 9 & 14 & \\
Indonesia & 9 & 14 & \\
Malaysia & 9 & 14 & \\
Philippines & 9 & 14 & \\
Singapore & 9 & 14 & \\
Thailand & 9 & 14 & \\
Vietnam & 6 & 11 & \\
Laos & 4 & 9 & \\
Myanmar & 4 & 9 & \\
Cambodia & 2 & 7 & \\
Member: $i$ & & & \\
\hline
\end{tabular}

\section{A. Defining a New Set of RTA Variables}

The usual RTA's dummy variable assesses the impact of the RTA year after year. We propose a variable designed to assess the impact of the RTA after a given period of membership. The variable we propose is based on the count of the number of years each member has participated, combining the expansion dimension of the RTA (the evolution of the membership over time) and the cumulative cooperation experience of the members over time. For instance, let us consider the membership of the AFTA (see Appendix for the members and their date of accession). Let us call $Y P(i, t)$ the number of years of participation of member country $i$ in the RTA at date $t$. Table 2 illustrates AFTA members' participation in 2000 and 2005.

The traditional RTA dummy variables bunch up the observations in two groups: group 0 for non-members, group 1 for members. Focusing on the number of year of participation helps to bunch up the observations in $T$ groups, $T$ being the number of years the RTA has existed. For instance, Table 2 shows that Brunei in year 2000 will be bunch up with Laos in year 2005, so that the average trade residuals corresponding to 9 years of participation will include a very specific group of country-pairs depending of the evolution of the RTA's membership. This helps to evaluate the effect of being member of the RTA for one more year based on the full information available from all its members.

To compute the RTA variables, we distinguish between the exporter (country $i$ ) and the importer (country $j$ ). Each RTA is thus characterized by three variables 
representing respectively export flows from a member to a non-member $\left(V_{R T A-R O W}\right)$, export flows from a non-member to a member $\left(V_{R O W-R T A}\right)$, and export flows between members $\left(V_{R T A-R T A}\right)$. These variables depend on $i, j$ and $t$ :

$$
\begin{aligned}
& V_{\text {RTA-ROW }}(i, j, t)=Y P(i, t) \text {, if } i \text { belong to RTA and } j \text { does not } \\
& =0 \text {, otherwise } \\
& V_{R O W-R T A}(i, j, t)=Y P(j, t) \text {, if } j \text { belong to TRA and } i \text { does not } \\
& =0 \text {, otherwise } \\
& V_{\text {RTA-ROW }}(i, j, t)=\operatorname{Min}\{Y P(i, t), Y P(j, t)\} \text {, if } i \text { and } j \text { belong to RTA } \\
& =0 \text {, otherwise }
\end{aligned}
$$

To take account of anticipation effects from the beginning of the negotiation of the RTA to the end of the first year of existence, we have to start the analysis a certain number of years before the date of entry into force. We arbitrarily choose ten years, which is sufficient to capture any anticipation effect. ${ }^{17}$ Under this hypothesis, the RTA variables become:

$$
\begin{aligned}
\tilde{V}_{R T A-R O W}(i, j, t) & =Y P(i, t)+10, \text { if } i \text { belongs to } R T A \text { and } j \text { does not } \\
& =0, \text { otherwise } \\
\tilde{V}_{R T A-R O W}(i, j, t) & =Y P(j, t)+10, \text { if } i \text { belongs } t o r T A \text { and } j \text { does not } \\
& =0, \text { otherwise } \\
\tilde{V}_{R T A-R O W}(i, j, t)= & \operatorname{Min}\{Y P(i, t), Y P(j, t)\}+10, \text { if } i \text { and } j \text { belong to RTA } \\
= & 0, \text { otherwise. }
\end{aligned}
$$

\section{B. The Two-step Estimation Approach}

We propose a two-step estimation approach in which a gravity model not including any RTA variables is estimated in the first-step, and then the trade residuals are extracted and used in second step to run a kernel regression using the RTA variables. As discussed in the introduction, many recent papers have revisited the econometric tools to rigorously estimate the gravity equation. This paper takes

\footnotetext{
${ }^{17}$ Freund and McLaren (1999) estimate this period to be approximately 12 years.
} 
stock of these developments and uses the state-of-the-art fixed-effects and randomeffects formulations for the first-step. This approach provides the flexibility necessary to update the trade effects of any RTA as trade economists continue to explore the best way to estimate the gravity model.

The fixed-effects specification of the gravity model generally provides efficient and consistent estimators, although the impact of some trade determinants is ripped out depending on the specific fixed-effects included in the gravity equation. For instance, a country-pair fixed effects will rip off geographical variables like bilateral distance, common language, common currency... Baldwin and Taglioni (2006) propose the following improvements to the way the fixed-effect gravity model are specified: use unidirectional trade flows and include country-pair and time dummy variables, or country-time dummy variables. Their preferred specification is to include both country-pair and country-time dummy, although they acknowledge that since most of the trade policies examined by trade economists are country-pair specific, this approach alters the estimation of the trade impact of these policies. Against this backdrop, we propose an exporter-year fixedeffects specification with the inclusion of some bilateral geographical variables to partially control for the omitted country-pair dummies:

$$
\begin{aligned}
& \ln X_{i j t}=a_{0} \ln D i s t_{i j}+a_{1} \ln G D P_{j t}+a_{2} \ln P O P_{j t}+a_{3} \ln I N F R A_{j t} \\
& +a_{4} \ln R E M_{j t}+a_{5} \ln R E R_{i j t}+\sum_{k} b_{k} G e o_{i j}^{k}+c_{0} F E_{i t}+\delta_{0}+\varepsilon_{i j t}
\end{aligned}
$$

where $X_{i j t}$ is country $i$ 's export to country $j$ at period $t, D i s t_{i j}$ is the distance between country $i$ and $j, G D P_{j t}$ is the GDP of country $i$ in year $t, P O P_{j t}$ is the population of country $i$ in year $t, I N F R A_{j t}$ is a proxy for country's $j$ infrastructure stock in year $t$, $R E M_{j t}$ is remoteness variable suggested by Baier and Bergstrand (2002), $R E R_{i j t}$ is a measure of the real exchange rate between country $i$ and $j$ in year $t, F E_{i t}$ is the exporter-year fixed effects, $G e o_{i j}{ }^{k}$ is a set of $k$ geographical variables, $\mathrm{d}_{0}$ is an

${ }^{18} \mathrm{We}$ use the formulation proposed by Carrere (2006) to estimate the remoteness variable:

$$
R E M_{j t}=\left[\sum_{k=1, k \neq j}^{N} G D P_{k t} \times\left(D i s t_{i k}\right)^{1-\sigma}\right]^{1 / 1-\sigma} \text {, with } \mathrm{N} \text { being the total number of countries and } \sigma=4 .
$$

The real exchange rate variable is inspired by Soloaga and Winters (2000): $R E R_{i j t}=\left(e \times \Pi_{U S, t} / \Pi_{i, t}\right) .\left(e \times \Pi_{U S, t} / \Pi_{j, t}\right)$ where $\mathrm{e}$ is the value of 1 US $\$$ evaluated in the currency of country $i$ and $\Pi$ is the GDP deflator. Note that $G D P_{i t}, P O P_{i t}$ and $I N F R A_{j t}$ are not included in equation (7) because their effects are ripped off by the inclusion of the exporter-year fixed effects $F E_{i t}$. 
intercept common to all years and country-pairs and $\varepsilon_{i j t}$ is the error term. ${ }^{18}$ The geographical variables included are: contiguity, landlockedness, common colonizer, and common language.

Because some time-invariant variables cannot be estimated in a fixed-effects specification, their effects are compounded in the error term, which would affect our proposed evaluation of the RTAs trade impact using trade residuals. Carrere (2006) proposes a Hausman-Taylor specification using country-specific random effects and correcting for the endogeneity of some regressors to ensure that the random effects are not correlated with them. Furthermore, she proposes to add three selection variables to correct for the unbalancedness of the panel: the number of years each country-pair is present in the database $\left(P R E S_{i j}\right)$, a dummy variable indicating that a country-pair is present in the database for the entire period $\left(D D_{i j}\right)$, and a dummy variable indicating that a country-pair in the database in year $t$ was also in the database in $t-1\left(P A_{i j t}\right){ }^{19}$ The specification used is the following:

$$
\begin{gathered}
\ln X_{i j t}=\alpha_{0} \ln D i s t_{i j}+\alpha_{1} \ln G D P_{i t}+\alpha_{2} \ln G D P_{j t}+\alpha_{3} \ln P O P_{i t}+ \\
\alpha_{4} \ln P O P_{j t}+\alpha_{5} \ln I N F R A_{i t}+\alpha_{6} \ln I N F R A_{j t}+\alpha_{7} \ln R E M_{i t}+ \\
\alpha_{8} \ln R E M_{j t}+\alpha_{9} \ln R E R_{i j t}+\alpha_{10} P R E S_{i j}+\alpha_{11} D D_{i j}+\alpha_{12} P A_{i j t}+ \\
\delta_{1}+\sum_{k} \beta_{k} G e o_{i j}^{k}+c_{1} R E_{i j}+\eta_{i j t}
\end{gathered}
$$

where $R E_{i j}$ represents the random effects and $\eta_{i j t}$ is the error term. The estimated residuals of equations (7) and (8) are extracted and used in the second step for the non-parametric part of the estimation.

To simply describe the kernel regression used in the second step, let us imagine a scatter plot depicting the estimated trade residuals $\left(\hat{\varepsilon}_{i j t}\right.$ and $\left.\hat{\eta}_{i j t}\right)$ against one of the three RTA variables $\left(\tilde{V}_{R T A-R O W}(i, j, t), \tilde{V}_{R O W-R T A}(i, j, t)\right.$, or $\left.\tilde{V}_{R T A-R T A}(i, j, t)\right)$. When the RTA variable equals to 1 , consider the average trade residuals for all the country-pairs bunched up as described in subsection A of this section. For the RTA variable equal to 2, consider the average trade residuals for all the country-pairs bunched up, and so on. As for these average trade residuals, the goal of the kernel regression is to evaluate the non-parametric function $f($.) underlining the variation of $\hat{\varepsilon}_{i j t}\left(\hat{\eta}_{i j t}\right)$ in accordance with $\tilde{V}_{R T A-R O W}(i, j, t), \tilde{V}_{R O W-R T A}(i, j, t)$, or $\left.\tilde{V}_{R T A-R T A}(i, j, t)\right)$ by using a kernel estimator, that is defined as:

\footnotetext{
${ }^{19} \mathrm{We}$ also include these three variables in the fixed-effects specification for the sake of comparability of the estimated trade residuals.
} 


$$
\begin{aligned}
& E\left(\varepsilon_{i j t} \mid V_{R T A-R O W}(i, j, t)\right)=\hat{f}\left(V_{R T A-R O W}(i, j, t)\right) \\
& E\left(\varepsilon_{i j t} \mid V_{R O W-R T A}(i, j, t)\right)=\hat{f}\left(V_{R O W-R T A}(i, j, t)\right) \\
& E\left(\varepsilon_{i j t} \mid V_{R T A-R T A}(i, j, t)\right)=\hat{f}\left(V_{R T A-R T A}(i, j, t)\right)
\end{aligned}
$$

with:

$$
\hat{f}(x)=\frac{\sum_{i=1}^{n} K\left(x_{i}\right) \cdot \hat{\varepsilon}_{i j t} / \gamma_{n}}{\sum_{i=1}^{n} K\left(x_{i}\right) / \gamma_{n}}
$$

where $n$ is the number of observations, $\gamma_{n}$ is an a-priori chosen sequence of positive numbers called the window width parameter and $K($.$) is an a-priori chosen real$ function called the kernel, and satisfying $\int|K(x)| d x<\infty$ and $\int|K(x)| d x=1$. Bierens (1994) analyses the asymptotic property of this estimator, and shows that it is asymptotically normal, that is:

$$
\sqrt{n}[\hat{f}(x)-f(x)] \rightarrow N(0, V(x))
$$

where $V(\mathrm{x})$ depends on the characteristics of the kernel function $K(x)$. Bierens (1994) shows that the specific choice of the kernel function is not crucial since any Gaussian kernel would be relevant. ${ }^{20}$ More important is the choice of the bandwidth that controls the trade-off between bias and variance of the estimated trade effects. Since the RTA variables are discrete variables (number of years of participation), we choose a bandwidth $\gamma_{n=1}$ so as to smooth trade effects over a oneyear period. We also run the kernel regression using $\gamma_{n=0.5}$ and $\gamma_{n=1.5}$ for robustness check. Bierens (1994) describes in detail how to use equation (13) to directly build the Confidence Interval of the estimated trade effects, which we use to build the confidence interval of our estimated trade impacts.

\section{Empirical Analysis}

Our database encompasses the IMF DOTS trade database over 1962-2006 with

\footnotetext{
${ }^{20}$ It could be argued that the asymptotic properties derived by Bierens do not necessarily holds for an estimated variable such as the trade residuals used here. The alternative is to use a bootstrap approach to replicate the estimated residuals and then derive the confidence interval. We conducted this approach for a subset of RTAs and the derived confidence interval were barely different from those obtained using Bierens asymptotic results.
} 
the following data from the World Bank WDI database: GDP, population, exchange rates and number of telephone lines used as a proxy for countries' stock of infrastructures. ${ }^{21}$ The missing observations of the WDI variables were replaced by approximating them using the trend of the time series whenever enough data allowed it. This provides the largest database ever used to evaluate the trade impact of RTAs: 24,014 country-pairs over 45 year with some gaps for some countrypairs, yielding 428,374 observations. The final database is an unbalanced panel containing 176 exporters and 180 importers over the period 1962-2006.

Since unbalanced panels can induce some selection bias in the estimated trade effects, we use the correction method proposed by Nijman and Verbeck (1992) and used in Carrere (2006) to correct the trade impact of RTAs from this bias by including the three selection variables $P R E S_{i j}, D D_{i j}$ and $P A_{i j t}$ as in equation (8). Furthermore, because the time-span of the panel we use is quite long (45 years), we need to make sure that any unit root problem is ruled out since such situation would lead to spurious estimates. We tested the GDP, population, real exchange rates and infrastructure series by simply running an $A R(1)$ model of these series and using a Wald test to test for a correlation coefficient different from 1, which helped to rule out the existence of unit roots. Finally, we tested the endogeneity of regressors as requested by a Hausman-Taylor specification by performing a Durbin-Wu-Hausman endogeneity test on all the regressors. The GDP and infrastructures variables were found to be the time-dependent endogenous regressors, while the variables distance, contiguity, common colonizer and common languages were found to be the time-invariant endogenous regressors. The Hausman-Taylor specification corrects for these endogeneity problems.

In the second step, we extracted the estimated trade residuals from equations (7) and (8), and run a kernel regression as described in subsection B of section III. We then used equation (13) to build the confidence interval as follows: for each grid point, we consider the standard deviation $(\sigma)$ from equation (13) and use it to compute the $95 \%$ confidence interval of the trade effects defined as $\pm 1.96 \times \sigma$, where $\sigma=\sqrt{1 /(12 n)}, n$ being the total number of years of existence of a given RTA and $1 / 12$ being the variance of the uniform distribution. ${ }^{22}$ The results are presented graphically in Appendix. For the sake of robustness check, we also run the kernel regressions using respectively a bandwidth of 0.5 and 1.5 and found

\footnotetext{
${ }^{21}$ We did not use the composite infrastructure used by Carrere (2006) following Limao and Venables (2001) because we couldn't replicate them for period 1962-2006 due to too many missing observations. ${ }^{22}$ See Bierens (1994) for a full explanation of this process.
} 
Table 3. Estimations of the Gravity Equation

\begin{tabular}{|c|c|c|}
\hline & \multicolumn{2}{|c|}{ Dependent variable: $\operatorname{LnX}_{i j t}$} \\
\hline & Fixed-Effects & Hausman-Taylor \\
\hline $\operatorname{lnDist}_{i j}$ & $-1.23^{\mathrm{a}}(-283.03)$ & $-2.17^{\mathrm{a}}(-7.70)$ \\
\hline $\operatorname{lnGDP}_{i t}$ & & $1.47^{\mathrm{a}}(107.31)$ \\
\hline $\operatorname{lnGDP}_{j t}$ & $0.55^{\mathrm{a}}(118.90)$ & $0.60^{\mathrm{a}}(61.31)$ \\
\hline $\ln \mathrm{POP}_{i t}$ & & $-0.67^{a}(-32.69)$ \\
\hline $\ln \mathrm{POP}_{j t}$ & $-0.04^{\mathrm{a}}(-14.88)$ & $0.13^{\mathrm{a}}(7.77)$ \\
\hline $\operatorname{lnINFRA~}_{i t}$ & & $0.19^{\mathrm{a}}(27.07)$ \\
\hline $\operatorname{lnINFRA~}_{j t}$ & $0.23^{\mathrm{a}}(56.93)$ & $0.20^{\mathrm{a}}(32.60)$ \\
\hline $\operatorname{lnREM}_{i t}$ & & $0.23^{\mathrm{a}}(10.26)$ \\
\hline $\operatorname{lnREM}_{j t}$ & $0.01^{\mathrm{b}}(3.01)$ & $0.01(1.20)$ \\
\hline $\operatorname{lnRER}_{i j t}$ & $-0.01^{\mathrm{a}}(-13.47)$ & $-0.06^{\mathrm{a}}(-34.60)$ \\
\hline $\operatorname{PRES}_{i j}$ & $0.05^{\mathrm{a}}(102.96)$ & $0.04^{\mathrm{a}}(5.77)$ \\
\hline $\mathrm{DD}_{i j}$ & $0.29^{\mathrm{a}}(27.13)$ & $0.65^{\mathrm{a}}(2.61)$ \\
\hline $\mathrm{PA}_{i j t}$ & $1.11^{\mathrm{a}}(71.38)$ & $0.49^{\mathrm{a}}(62.69)$ \\
\hline $\mathrm{LL}_{i}$ & & $-0.13(-0.70)$ \\
\hline $\mathrm{LL}_{j}$ & $-0.55^{\mathrm{a}}(-59.93)$ & $-1.21^{\mathrm{a}}(-6.60)$ \\
\hline Contiguity & $0.65^{\mathrm{a}}(32.67)$ & $15.97^{\mathrm{a}}(3.44)$ \\
\hline Com_colonizer & $0.66^{\mathrm{a}}(47.32)$ & $25.52^{\mathrm{a}}(8.18)$ \\
\hline Com_language & $0.56^{\mathrm{a}}(58.92)$ & $-9.79^{a}(-6.08)$ \\
\hline Constant & $0.44^{\mathrm{a}}(6.51)$ & $-21.54^{\mathrm{a}}(-9.57)$ \\
\hline Specific effects & Export-year FE & Country-pair RE \\
\hline Observations & 427,727 & 427,727 \\
\hline $\mathrm{R}^{2}$ & 0.36 & \\
\hline$\rho$ & & 0.97 \\
\hline$P$-value & 0.00 & 0.00 \\
\hline
\end{tabular}

Note: $\rho$ is the share of the variance explained by country-pair effects

very similar results, which imply that for $\gamma_{n} \in[0.5 ; 1.5]$, the estimated trade effects are similar to the one presented in Appendix.

\section{A. The Gravity Equation Results}

The estimation results of the gravity equations are reported in Table 3 . The first specification corresponds to equation (7) including exporter-year fixed effects and the second specification corresponds to equation (8) using the Hausman-Taylor specification. A parameter with an upper index $a$ is significant at the $1 \%$ level, that with an upper index $b$ is significant at the 5\% level and that with an upper index $c$ is significant at the $10 \%$ level. The $t$ - or $z$-statistics are in brackets.

The distance and GDP variables are statistically significant and depict the 
expected sign: distance negatively impacts bilateral trade flows while higher GDP induce higher trade. The Hausman-Taylor specification yields a larger trade friction due to distance than the fixed-effects estimator, but their GDP coefficients are of the same magnitude. The population variable yields different signs for both specifications, but their interpretations can be reconciled. Indeed, the fixed-effects estimator suggests that the larger the population of the importing country, the lower its imports which highlights the existence of home market discrepancy. On the other hand, the Hausman-Taylor specification indicates that the larger the population of the exporting country, the lower its exports which also suggests a home market bias. However, the Hausman-Taylor specification also shows that a larger population in the importing country boosts the exports of the exporting country given the larger demand it faces.

The infrastructure proxy confirms that the better the level of infrastructure of each trading partners, the larger trade flows through improved accessibility. The remoteness variable yields less intuitive positive coefficients, while the negative coefficient for the real exchange rate illustrates the competitiveness effect of a low exchange rate. The selection-bias variables yield statistically significant positive estimates, which suggest the relevance of their inclusion to correct for the upward bias induced by an unbalanced panel over-representing countries with a larger capacity to export. The geographical variables yield statistically significant coefficients with the expected sign, except for the unusual negative estimate of the common language dummy variable in the Hausman-Taylor specification.

Given the central place of the trade residuals in the semi-parametric approach proposed in this paper, it is very important to make sure that these residuals are not affected by omitted variables problems. The Hausman-Taylor specification is therefore a better approach since it allows controlling for all the relevant trade determinants we can think of. We tried to run a Hausman-Taylor specification including all the 22 RTAs with the three variables as described in subsection A of section III, but our quite powerful computer lacked enough capacity to do it. The semi-parametric approach proposed in this paper provides a rigorously estimated trend based on the whole database for each of the 22 RTAs. It also provides a confidence interval for each of these trends.

\section{B. The Trade Effect of RTAs}

Equation (7) and (8) are estimated respectively with an exporter-year fixedeffects estimator and a random effect (Hausman-Taylor) estimator, and the trade 
residuals are extracted and used with the RTA variables to run a series of kernel regressions. Each RTA variable is computed to reflect the 10 years of anticipation suggested by Freud and McLaren (1999). The results for the 22 RTAs are presented in Appendix. In these graphs, the dashed lines represent the estimated $95 \%$ confidence interval. We also plot a bold vertical line corresponding to the date of accession of any RTA member, and a fine vertical line corresponding to 5 years before this accession. For the sake of conciseness, the following comments focus in more detail on the 9 RTAs that depict a negative intra-RTA when included in equation (8) and then overview some of the well-known RTAs. Since RTAs are expected to at least increase intra-regional trade, these nine cases help to explore more this unusual pattern.

The graphs for ArFTA indicate a positive and slightly increasing trend for the intra-RTA residuals with the exporter-year fixed effects estimator yielding a larger effect than the Hausman-Taylor specification. However, given that the fixed-effects estimator excludes all the variables that are specific to each exporter-year, we will use the Hausman-Taylor estimator as our preferred specification. ArFTA appears to have barely generated intra-regional trade while it has been having a significantly negative impact on its members' imports from the rest of the world, which suggests that it has been more trade diverting than trade creating. ArFTA exports to the rest of the world have also been negative, although with an upward trend. The graphs also suggest a slight anticipation effect on intra-ArFTA exports five year before the agreement entered into force.

BIMSTEC appears to have had an increasing negative impact on intraBIMSTEC exports, compounded with a slightly negative trend of BIMSTEC's imports from the rest of the world. However, the RTA exports to the rest of world have a slightly positive and increasing trend, which suggests that the agreement have been more beneficial for the rest of the world than for the members. The graphs even suggest an anticipation effect on BIMSTEC exports ten years before its date of entry into force.

Intra-CACM exports appear to have been below potential for the entire existence of the RTA, whereas the RTA's imports from the rest of the world have been slightly positive and increasing, with a five-year anticipation effect. The RTA seems to have had an increasing negative impact on its members' exports to the rest of the world, suggesting a globally ineffective RTA in terms of trade impact.

CARICOM appears to have had a positive impact on its intra-regional exports and its exports to the rest of the world during its 15 first years of existence, and 
then started to have a negative impact. The RTA seems to have had no impact on its members' imports from the rest of the world. The initial positive impact of the RTA on its intra-regional exports appears to have been anticipated five year before its date of entry into force.

CEMAC appears to have had a negative impact on its members' intra-regional exports as well as on their exports to and imports from the rest of the world. No anticipation effect is detectable. The graphs also shows a large variability in the intra-regional trade residuals ten years before the date of entry into force of the RTA, probably reflecting the large macroeconomics imbalances that led to the devaluation of the common currency of CEMAC members in the 1990s.

Given that most of the CIS countries were part of the Soviet Union before 1990, their bilateral trade flows can not be traced for a longer period as with the other countries. Our estimations suggest that CIS have had a positive impact on its members' intra-regional early at the creation of the RTA, but faltered over time to be slightly negative. Its impact on their imports from the rest of the world seems to have been positively increasing although close to zero, and no impact is detected on its members' exports to the rest of the world.

SADC impact on its members trade appears to have been fluctuating around zero ten year before its creation and thereafter. SAPTA seems to have had a slightly positive impact on its members' intra-regional exports, but a slightly negative impact on their imports from the rest of the world. Its impact on their exports to the rest of the world appears to be null. WAEMU seems to have had a positive impact on its members' intra-regional exports although decreasing in the beginning before starting to increase 8 years after its creation. Its impact on their exports to the rest of the world was positive in the beginning, and then turned negative. These variations are probably due to the socio-political instability the leading country of this RTA (Cote d'Ivoire) has been facing from1998 to 2003. WAEMU impact on its members' imports from the rest of the world has been slightly negative, suggesting a trade diversion.

The ASEAN free trade area appears to have had a positive impact on its members intra- and extra-regional exports, combined with a positive impact on their imports from the rest of the world during 6 years and then a null effect. This suggests that AFTA has been a quite successful RTA mostly trade creating and positively impacting the rest of the world through its extra-regional exports. The CAN and MERCOSUR also depict such positive outcome, with their impact on their members' intra-regional exports much higher than AFTA. NAFTA appears to 
have been trade creating with a positive impact on its members' intra-regional exports and imports from the rest of the world. Its impact on their exports to the rest of the world is less clear-cut. The Group of Three agreement involving Colombia, Mexico and Venezuela also appears to have been a successful RTA with an estimated positive impact on its members' intra- and extra-regional exports as well as on their imports from the rest of the world. The EU appears to have had a positive impact on its members' intra-regional exports, but a less clear-cut impact on their imports to or exports from the rest of the world. By and large, the trade impacts plotted in Appendix show that most of the RTAs have had at least a slightly positive impact on their intra-regional exports. The exceptions are BIMSTEC, CACM, CEMAC, EEU and GCC.

\section{Conclusion}

This paper proposes two contributions to the evaluation of RTAs' trade impacts. First, we use an RTA variable that takes into account the number of years each member has participated instead of the usual RTA dummy variable. Second, we combine traditional gravity regressions with non-parametric estimation techniques so as to capture the non-monotonic trade effects while imposing minimal structure on the model. This approach provides a common ground to evaluate the trade impact of RTAs since it can easily be adjusted to the state-of-the-art technique to estimate the gravity equation and allow including any new RTA in a straightforward way.

We focus on a panel of 22 RTAs mostly involving developing countries and covering all the continents. Except for BIMSTEC, CACM, CEMAC, EEU and GCC, all these RTAs appear to have had a positive impact on their members' intraregional exports. This work is based on the up-to-date estimation techniques of the gravity equation and the proposed semi-parametric estimation approach can be easily implemented to rigorously assess the trade impact of developing RTAs. Given the increasing number of RTA signed by developing countries with sometime a low technical capacity to deal with the complexity of computable general equilibrium trade models, this approach can be a key accessible and rigorous diagnostic tool to evaluate the prospected gains from these agreements. 


\section{Acknowledgments}

I thank Jeffrey Bergstrand, Paul Brenton, Marius Brülhart, Celine Carrère, Renato Flores, Lionel Fontagné, Guillaume Gaulier, Thierry Mayer, Daniel Mirza, Eric Toulemonde for helpful comments and suggestions at the various stages of this paper.

Received 12 April 2009, Revised 13 July 2009, Accepted 17 July 2009

\section{Appendix}

\section{A Panel of Developing RTAs}

South and East Asian and Pacific RTAs

\begin{tabular}{|c|c|c|c|}
\hline Agreement & Full Name & Membership Evolution & Type \\
\hline AFTA & $\begin{array}{c}\text { ASEAN } \\
\text { Free Trade } \\
\text { Agreement }\end{array}$ & $\begin{array}{l}\text { 1992: Brunei Darussalam } \\
\text { 1992: Indonesia } \\
\text { 1992: Malaysia } \\
\text { 1992: Philippines } \\
\text { 1992: Singapore } \\
\text { 1992: Thailand } \\
\text { 1995: Vietnam } \\
\text { 1997: Laos } \\
\text { 1997: Myanmar } \\
\text { 1999: Cambodia }\end{array}$ & $\begin{array}{c}\text { Political } \\
\text { Association }\end{array}$ \\
\hline Agreement & Full Name & Membership Evolution & Type \\
\hline SAPTA & $\begin{array}{l}\text { South Asia } \\
\text { Preferential } \\
\text { Trade } \\
\text { Agreement }\end{array}$ & $\begin{array}{l}\text { 1993: Bangladesh } \\
\text { 1993: Bhutan } \\
\text { 1993: India } \\
\text { 1993: Maldives } \\
\text { 1993: Nepal } \\
\text { 1993: Pakistan } \\
\text { 1993: Sri Lanka }\end{array}$ & $\begin{array}{l}\text { Preferential } \\
\text { Agreement }\end{array}$ \\
\hline Agreement & Full Name & Membership Evolution & Type \\
\hline BIMSTEC & $\begin{array}{c}\text { Bangladesh India } \\
\text { Myanmar Sri Lanka } \\
\text { Thailand Economic } \\
\text { Cooperation }\end{array}$ & $\begin{array}{l}\text { 1997: Bangladesh } \\
\text { 1997: Myanmar } \\
\text { 1997: India } \\
\text { 1997: Sri Lanka } \\
\text { 1997: Thailand }\end{array}$ & $\begin{array}{l}\text { Preferential } \\
\text { Agreement }\end{array}$ \\
\hline
\end{tabular}




\begin{tabular}{cclc}
\hline Agreement & Full Name & \multicolumn{1}{c}{ Membership Evolution } & Type \\
\hline & & 1981: Australia & \\
& & 1981: Cook Islands & \\
& 1981: Fiji & \\
& & 1981: Kiribati & \\
SPARTECA & South Pacific & 1981: Marshall Islands & \\
& Regional Trade & 1981: Micronesia & Preferential \\
& and Economic & 1981: Nauru & \\
& Cooperation & 1981: New Zealand & \\
& Agreement & 1981: Papua New Guinea & \\
& & 1981: Solomon Islands & \\
& & 1981: Tonga & \\
& & 1981: Vanuatu & \\
& & & \\
& &
\end{tabular}

Western Hemisphere RTAs

\begin{tabular}{|c|c|c|c|}
\hline Agreement & Full Name & Membership Evolution & Type \\
\hline CACM & $\begin{array}{l}\text { Central } \\
\text { American } \\
\text { Common } \\
\text { Market }\end{array}$ & $\begin{array}{l}\text { 1990: El Salvador } \\
\text { 1990: Guatemala } \\
\text { 1990: Honduras } \\
\text { 1990: Nicaragua } \\
\text { 1990: Dominican Republic } \\
\text { 1990: Costa Rica }\end{array}$ & $\begin{array}{l}\text { Customs } \\
\text { Union }\end{array}$ \\
\hline Agreement & Full Name & Membership Evolution & Type \\
\hline CAN & $\begin{array}{c}\text { Andean } \\
\text { Community }\end{array}$ & $\begin{array}{l}\text { 1988: Bolivia } \\
\text { 1988: Columbia } \\
\text { 1988: Ecuador } \\
\text { 1988: Peru } \\
\text { 1988: Venezuela }\end{array}$ & $\begin{array}{l}\text { Preferential } \\
\text { Arrangement }\end{array}$ \\
\hline Agreement & Full Name & Membership Evolution & Type \\
\hline MERCOSUR & $\begin{array}{c}\text { Southern } \\
\text { Common } \\
\text { market }\end{array}$ & $\begin{array}{l}\text { 1991: Argentina } \\
\text { 1991: Brazil } \\
\text { 1991: Paraguay } \\
\text { 1991: Uruguay }\end{array}$ & $\begin{array}{l}\text { Customs } \\
\text { Union }\end{array}$ \\
\hline
\end{tabular}




\begin{tabular}{lllc}
\hline Agreement & Full Name & \multicolumn{1}{c}{ Membership Evolution } & Type \\
\hline & & 1973: Antigua and Barbuda & \\
& & 1973: Bahamas & \\
& 1973: Barbados & \\
& 1973: Belize & \\
& 1973: Dominica & Political \\
& & 1973: Grenada & Association \\
CARICOM & Caribbean & 1973: Guyana & \\
& Commonity and & 1973: Haiti & \\
& Market & 1973: Jamaica & \\
& & 1973: Montserrat & \\
& & 1973: St. Vincent and the Grenadines & \\
& & 1973: St. Kitts and Nevis & \\
& & 1973: St. Lucia & \\
& & 1973: Suriname & \\
& & 1973: Trinidad and Tobago & \\
\end{tabular}

\begin{tabular}{cclc}
\hline Agreement & Full Name & Membership Evolution & Type \\
\hline \multirow{2}{*}{ GOT } & Group of & 1995: Colombia & Preferential \\
& Three & 1995: Mexico & Agreement \\
\hline
\end{tabular}

Sub-Saharan African RTAs

\begin{tabular}{llll}
\hline Agreement & Full Name & Membership Evolution & Type \\
\hline & & 1975: Benin & \\
& 1975: Burkina Faso & \\
& 1975: Cape Verde & \\
& 1975: Côte d'Ivoire & \\
& 1975: Gambia & \\
& & \\
& & 1975: Ghana & Political \\
ECOWAS & 1975: Guinea & Association \\
& Economic & 1975: Guinea Bissau & \\
& Community & 1975: Liberia & \\
& & 1975: Mali & \\
& & 1975: Niger & \\
& & $1975:$ Senegal & \\
& & $1975:$ Sierra Leone & \\
& & $1975:$ Togo & \\
& &
\end{tabular}




\begin{tabular}{|c|c|c|c|}
\hline Agreement & Full Name & Membership Evolution & Type \\
\hline SADC & $\begin{array}{c}\text { South African } \\
\text { Development } \\
\text { Community }\end{array}$ & $\begin{array}{l}\text { 1992: Angola } \\
\text { 1992: Botswana } \\
\text { 1992: DR Congo } \\
\text { 1992: Lesotho } \\
\text { 1992: Malawi } \\
\text { 1992: Mauritius } \\
\text { 1992: Mozambique } \\
\text { 1992: Namibia } \\
\text { 1992: Seychelles } \\
\text { 1992: South-Africa } \\
\text { 1992: Swaziland } \\
\text { 1992: Tanzania } \\
\text { 1992: Zambia } \\
\text { 1992: Zimbabwe }\end{array}$ & $\begin{array}{c}\text { Political } \\
\text { Association }\end{array}$ \\
\hline
\end{tabular}

\begin{tabular}{|c|c|c|c|}
\hline Agreement & Full Name & Membership Evolution & Type \\
\hline CEMAC & $\begin{array}{l}\text { Economic and } \\
\text { Monetary Commu- } \\
\text { nity of Central } \\
\text { Africa }\end{array}$ & $\begin{array}{l}\text { 1999: Cameroon } \\
\text { 1999: Central African Republic } \\
\text { 1999: Chad } \\
\text { 1999: Congo } \\
\text { 1999: Equatorial Guinea } \\
\text { 1999: Gabon }\end{array}$ & $\begin{array}{l}\text { Preferential } \\
\text { Arrangement }\end{array}$ \\
\hline Agreement & Full Name & Membership Evolution & Type \\
\hline EAC & $\begin{array}{l}\text { East African } \\
\text { Community }\end{array}$ & $\begin{array}{l}\text { 2000: Kenya } \\
\text { 2000: Tanzania } \\
\text { 2000: Uganda } \\
\text { 2000: Burundi } \\
\text { 2000: Rwanda }\end{array}$ & $\begin{array}{c}\text { Free trade } \\
\text { Arrangement }\end{array}$ \\
\hline Agreement & Full Name & Membership Evolution & Type \\
\hline SACU & $\begin{array}{c}\text { Southern } \\
\text { Africa Customs } \\
\text { Union }\end{array}$ & $\begin{array}{l}\text { 1970: Botswana } \\
\text { 1970: Lesotho } \\
\text { 1970: Namibia } \\
\text { 1970: South Africa } \\
\text { 1970: Swaziland }\end{array}$ & Customs Union \\
\hline
\end{tabular}




\begin{tabular}{|c|c|c|c|}
\hline Agreement & Full Name & Membership Evolution & Type \\
\hline WAEMU & $\begin{array}{l}\text { West Africa Eco- } \\
\text { nomic and Monetary } \\
\text { Union }\end{array}$ & $\begin{array}{l}\text { 1994: Benin } \\
\text { 1994: Burkina Faso } \\
\text { 1994: Cote d'Ivoire } \\
\text { 1994: Guinea Bissau } \\
\text { 1994: Mali } \\
\text { 1994: Niger } \\
\text { 1994: Senegal } \\
\text { 1994: Togo }\end{array}$ & Economic Union \\
\hline
\end{tabular}

Middle East and North Africa RTAs

\begin{tabular}{|c|c|c|c|}
\hline Agreement & Full Name & Membership Evolution & Type \\
\hline ArFTA & Arab Free Trade Area & $\begin{array}{l}\text { 1997: Bahrain } \\
\text { 1997: Egypt } \\
\text { 1997: Iraq } \\
\text { 1997: Jordan } \\
\text { 1997: Kuwait } \\
\text { 1997: Lebanon } \\
\text { 1997: Libya } \\
\text { 1997: Morocco } \\
\text { 1997: Qatar } \\
\text { 1997: Saudi Arabia } \\
\text { 1997: Syria } \\
\text { 1997: Tunisia } \\
\text { 1997: United Arab Emirates }\end{array}$ & $\begin{array}{l}\text { Free trade agree- } \\
\text { ment }\end{array}$ \\
\hline Agreement & Full Name & Membership Evolution & Type \\
\hline GCC & $\begin{array}{c}\text { Gulf Cooperation } \\
\text { Council }\end{array}$ & $\begin{array}{l}\text { 1981: Bahrain } \\
\text { 1981: Kuwait } \\
\text { 1981: Oman } \\
\text { 1981: Qatar } \\
\text { 1981: Saudi Arabia } \\
\text { 1981: United Arab Emirates }\end{array}$ & Political Association \\
\hline Agreement & Full Name & Membership Evolution & Type \\
\hline AMU & Arab Maghreb Union & $\begin{array}{l}\text { 1989: Morocco } \\
\text { 1989: Algeria } \\
\text { 1989: Tunisia } \\
\text { 1989: Mauritania } \\
\text { 1989: Libya }\end{array}$ & Political Association \\
\hline
\end{tabular}


Europe and Central Asian RTAs

\begin{tabular}{cccc}
\hline Agreement & Full Name & Membership Evolution & Type \\
\hline & & 1991: Armenia & \\
& & 1991: Azerbaijan & \\
& & 1991: Belarus & \\
& & 1991: Georgia & \\
CIS & & 1991: Kyrgyzstan & Political \\
& Commonwealth of & 1991: Moldova & Association \\
& & 1991: Russia & \\
& & 1991: Tajikistan & \\
& & 1991: Ukraine & \\
& & 1991: Uzbekistan & \\
Agreementent States & & 1991: Kazakhstan & \\
\hline \multirow{4}{*}{ EEU } & Full Name & Membership Evolution & Type \\
& & 2000: Russia & \\
& Eurasian Eco- & 2000: Armenia & Political Association \\
& nomic Union & 2000: Kazakhstan & \\
\hline
\end{tabular}

\section{Graphs}

AFTA Estimated Trade Impact

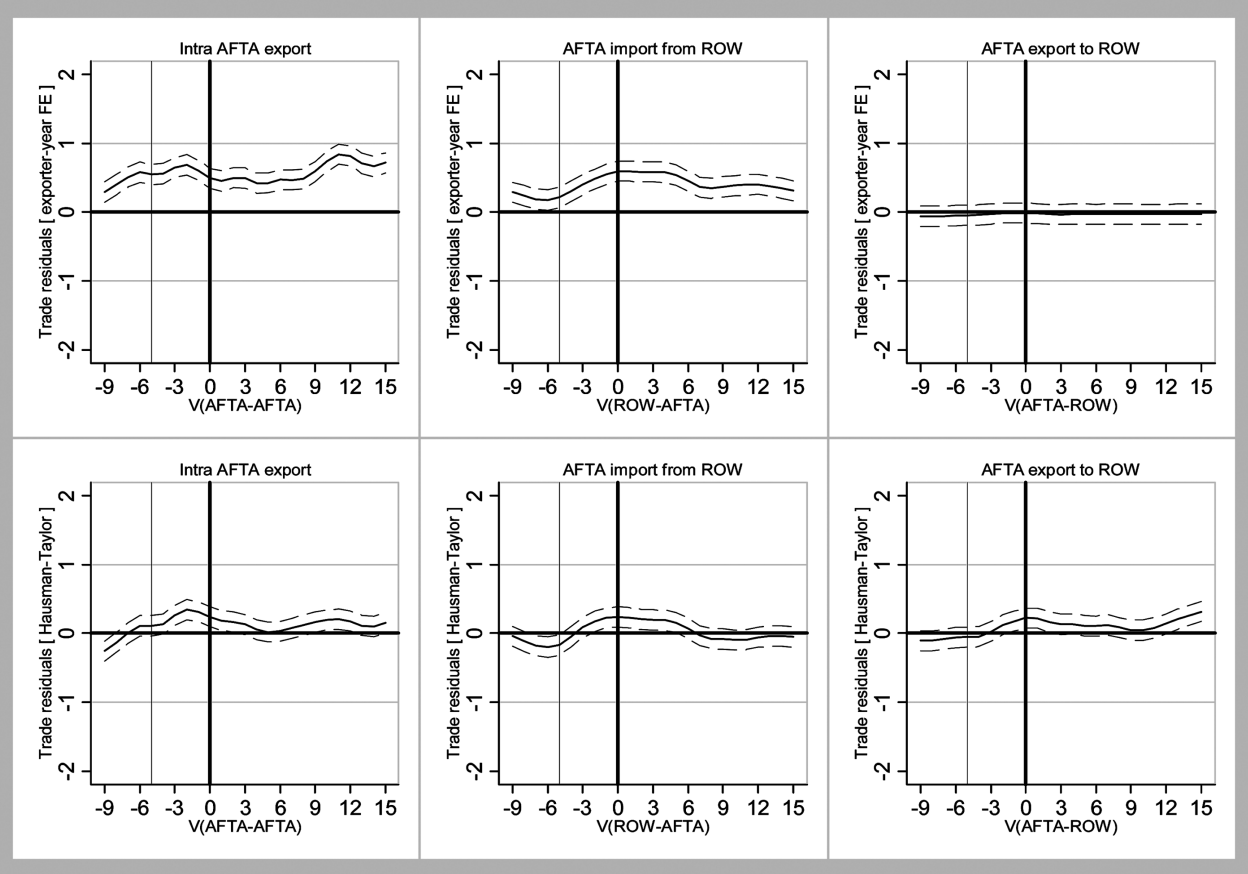


SAPTA Estimated Trade Impact
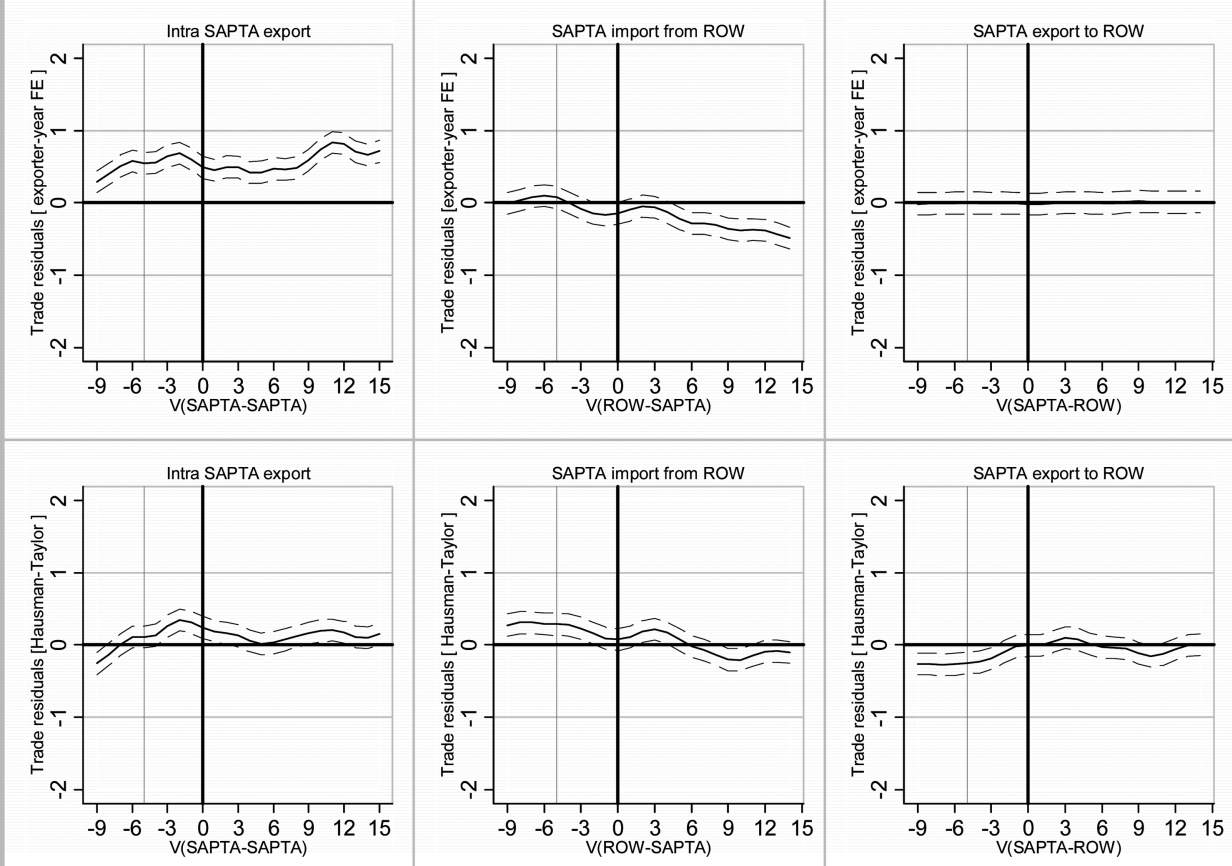

BIMSTEC Estimated Trade Impact
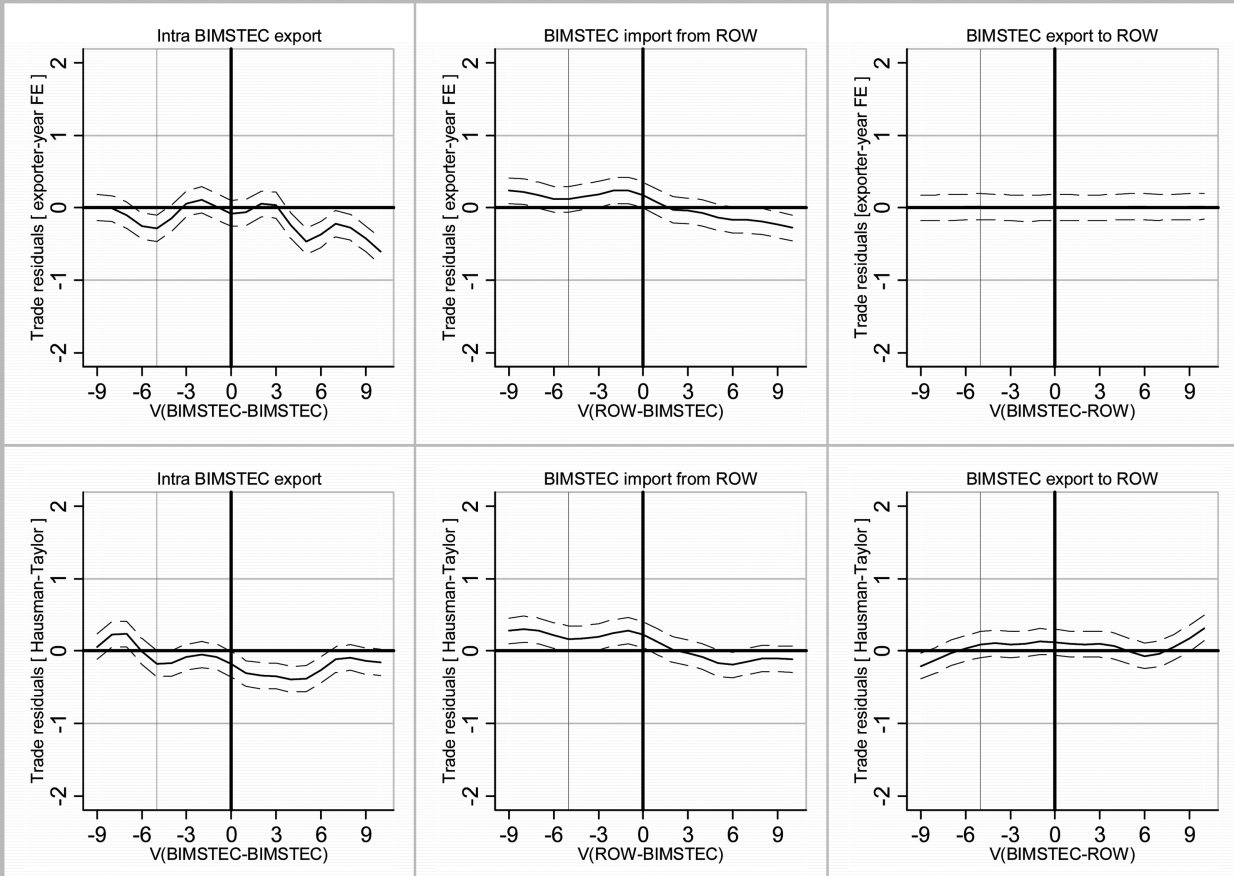


\section{SPARTECA Estimated Trade Impact}
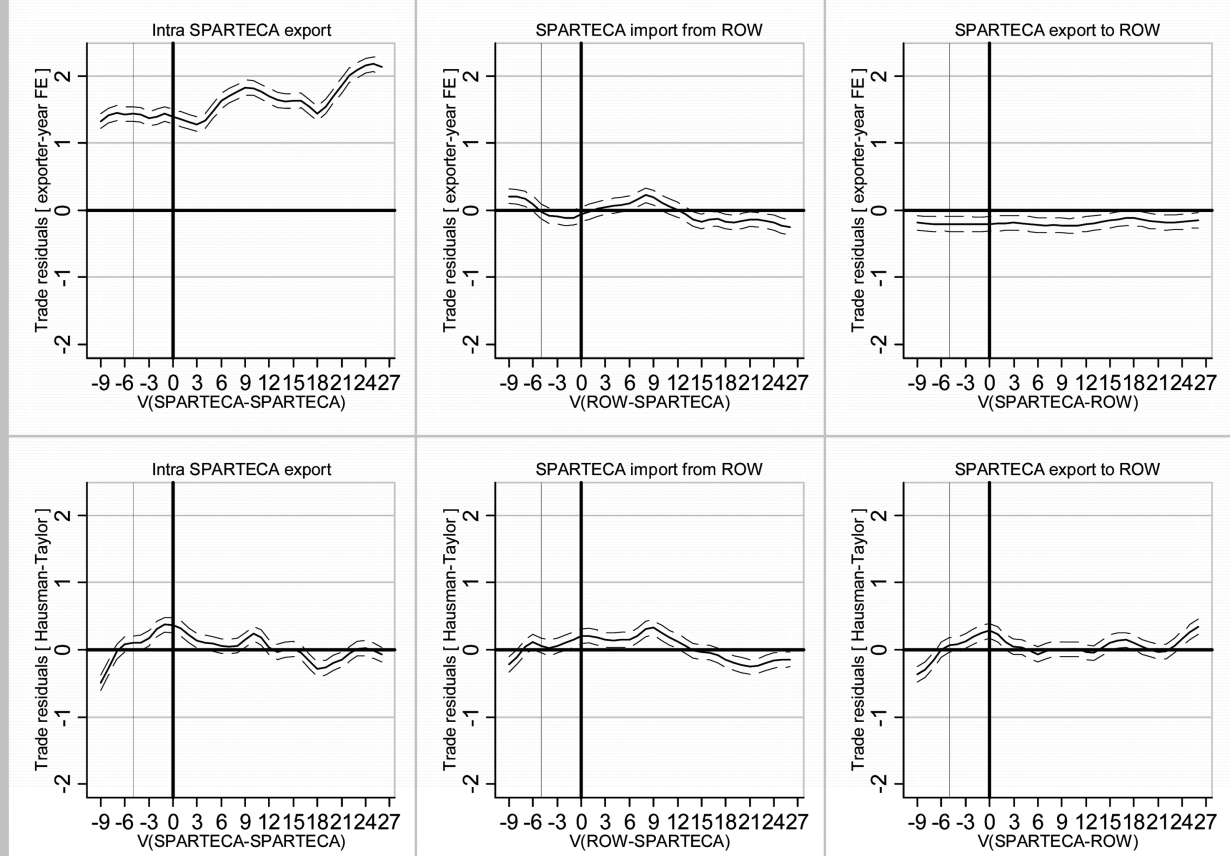

\section{CACM Estimated Trade Impact}
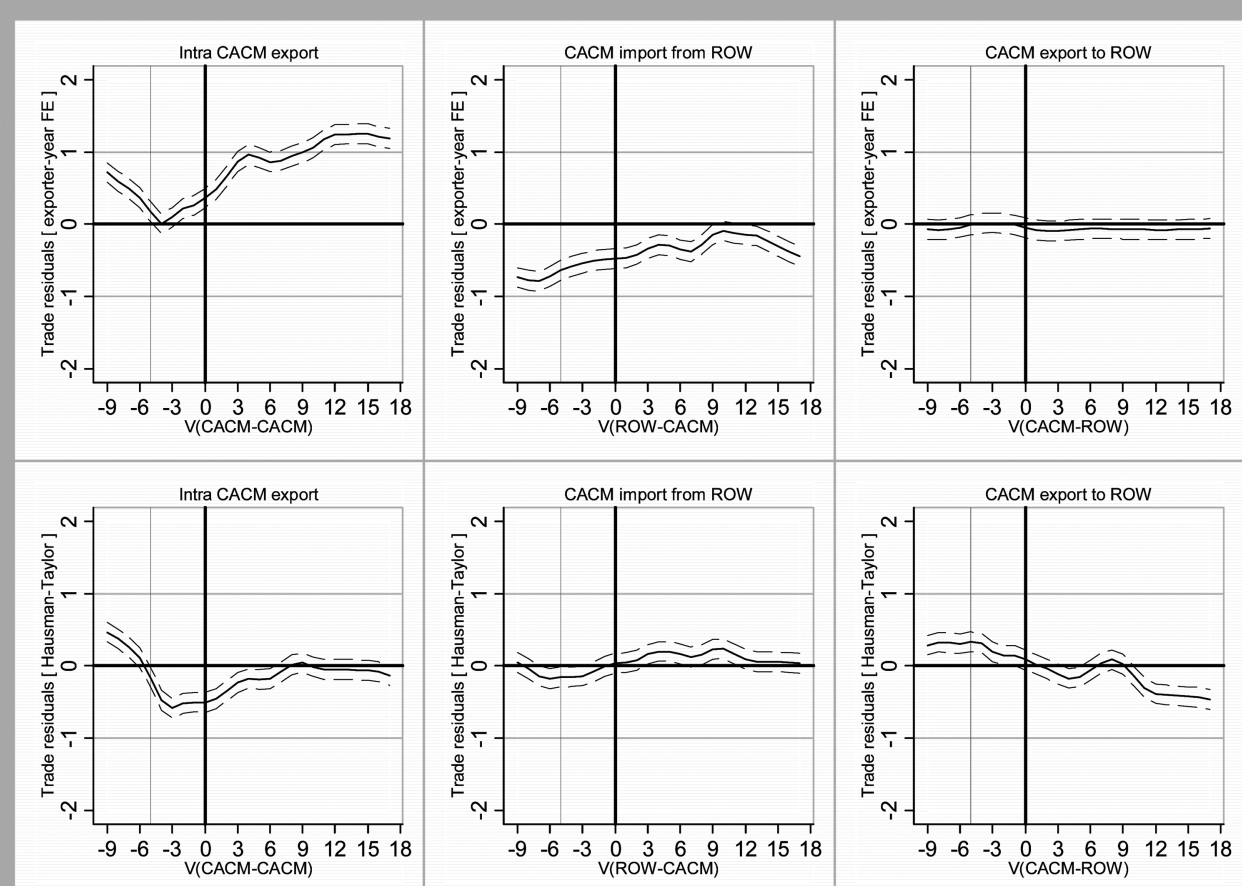
CAN Estimated Trade Impact

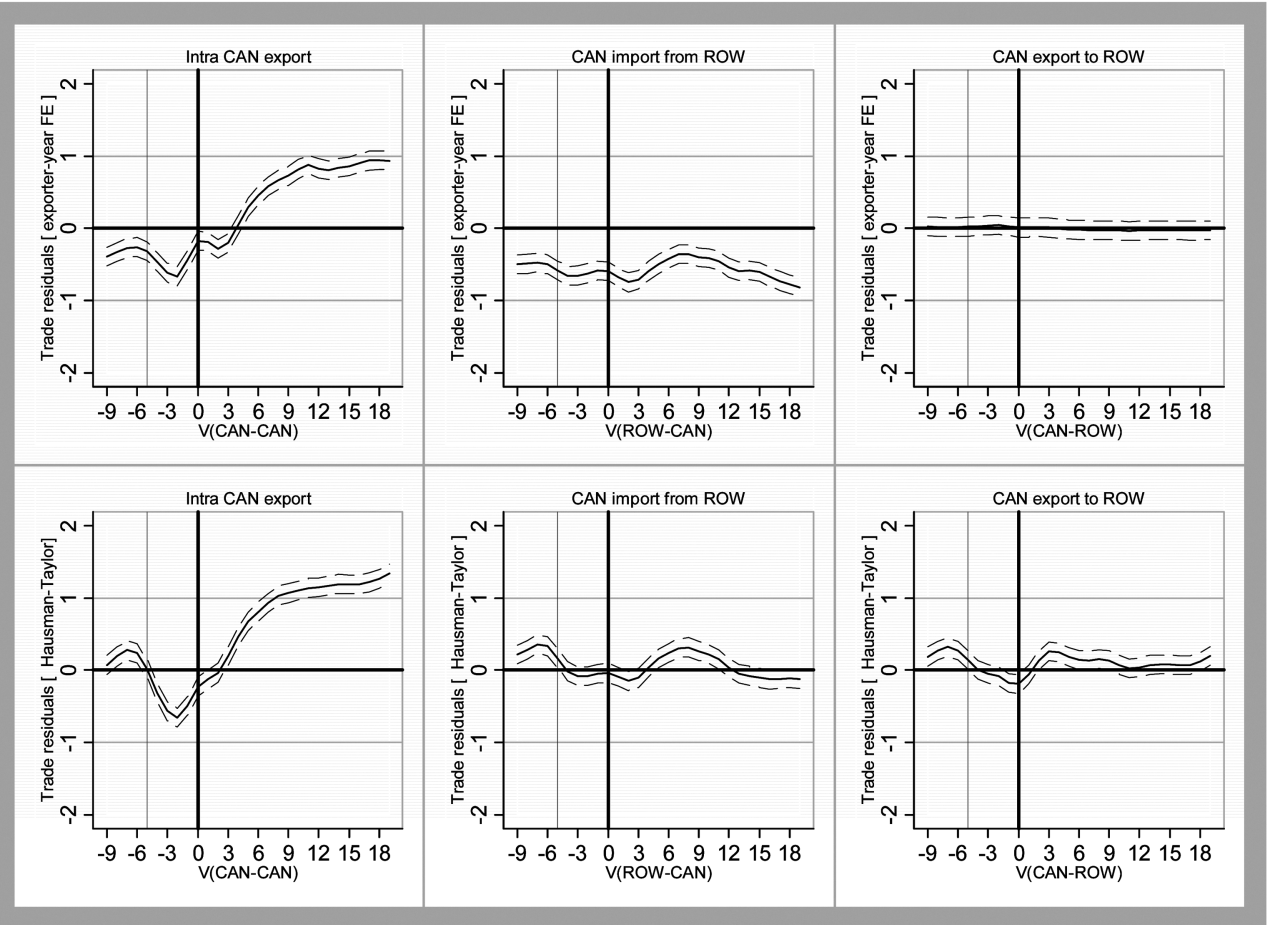

MERCOSUR Estimated Trade Impact

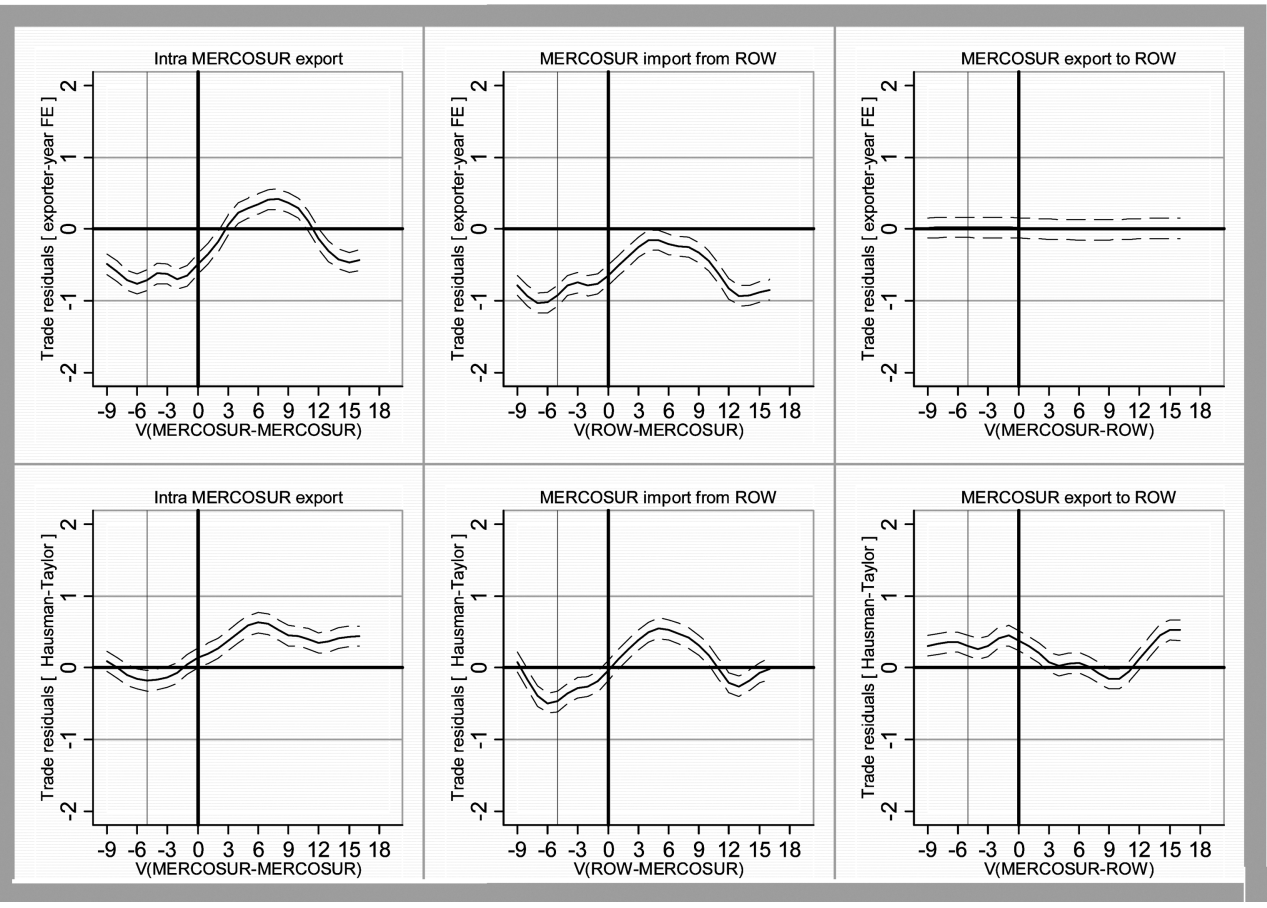


NAFTA Estimated Trade Impact
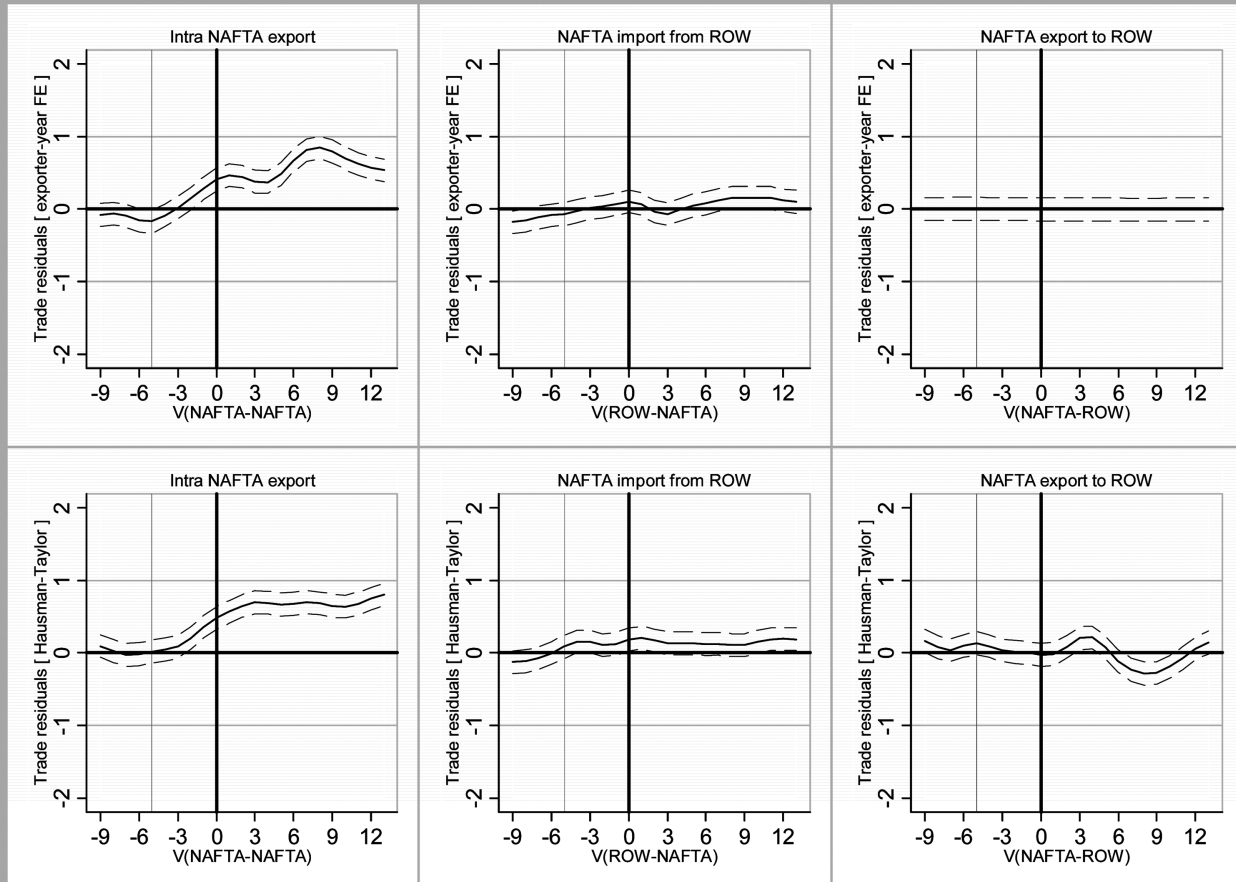

\section{CARICOM Estimated Trade Impact}

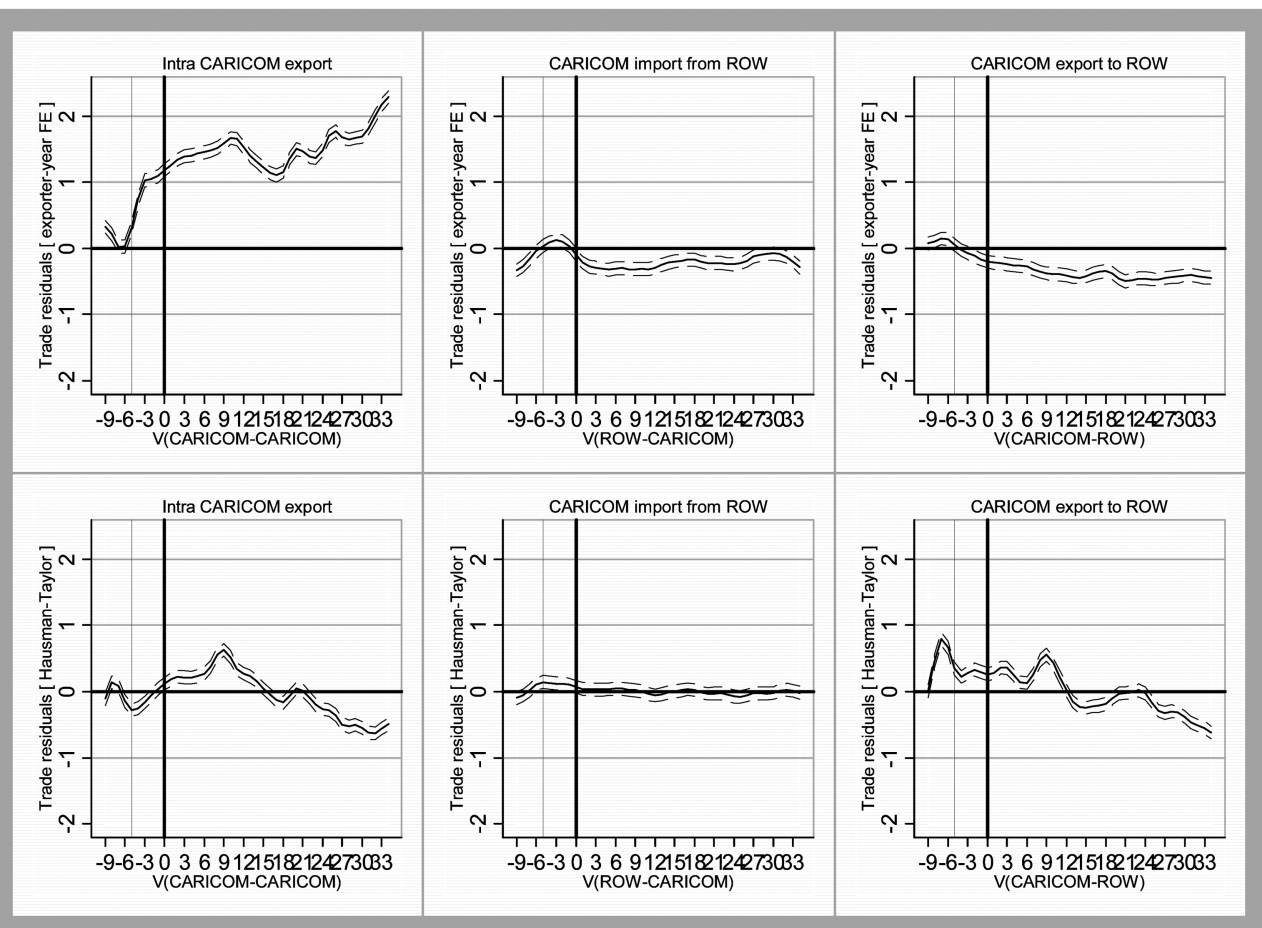


GOT Estimated Trade Impact
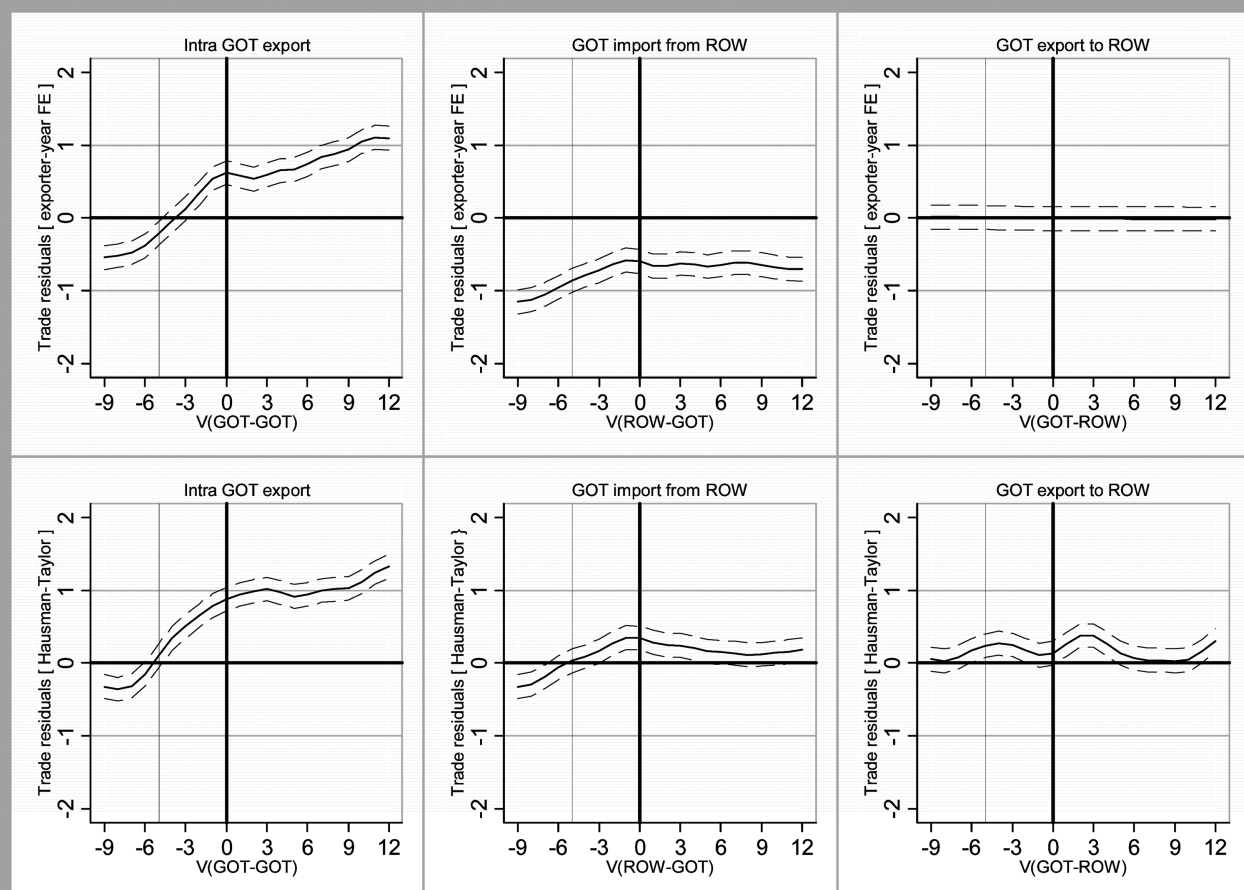

ECOWAS Estimated Trade Impact
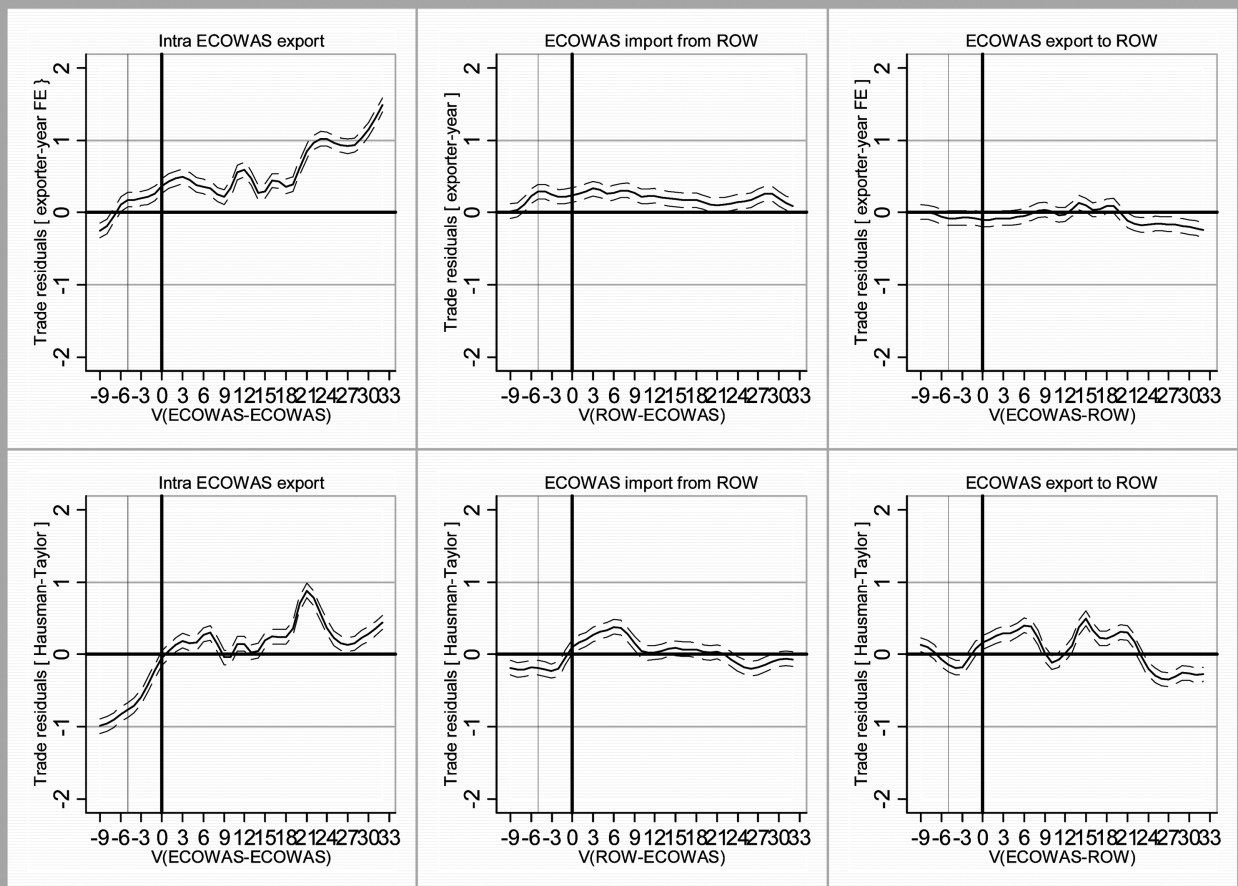
SADC Estimated Trade Impact
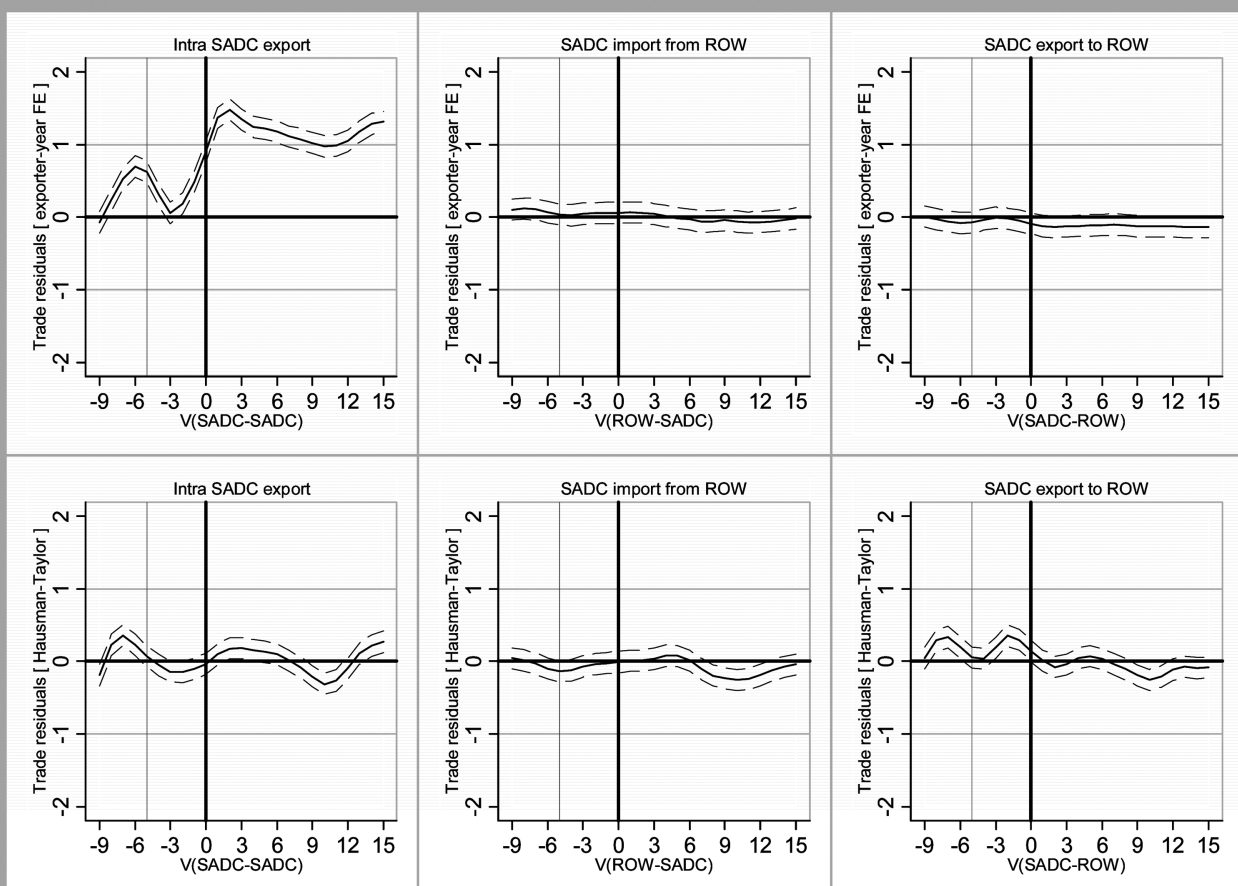

CEMAC Estimated Trade Impact
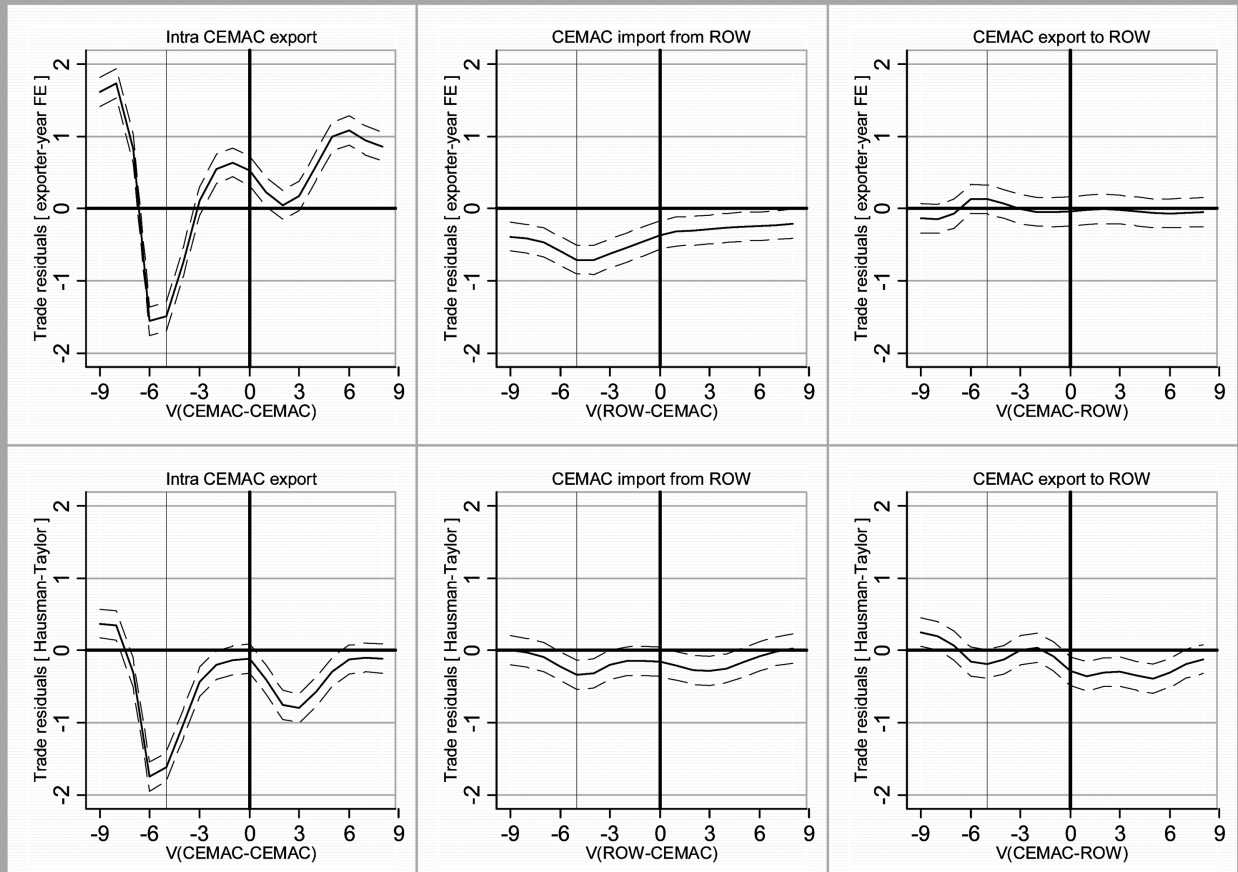
EAC Estimated Trade Impact

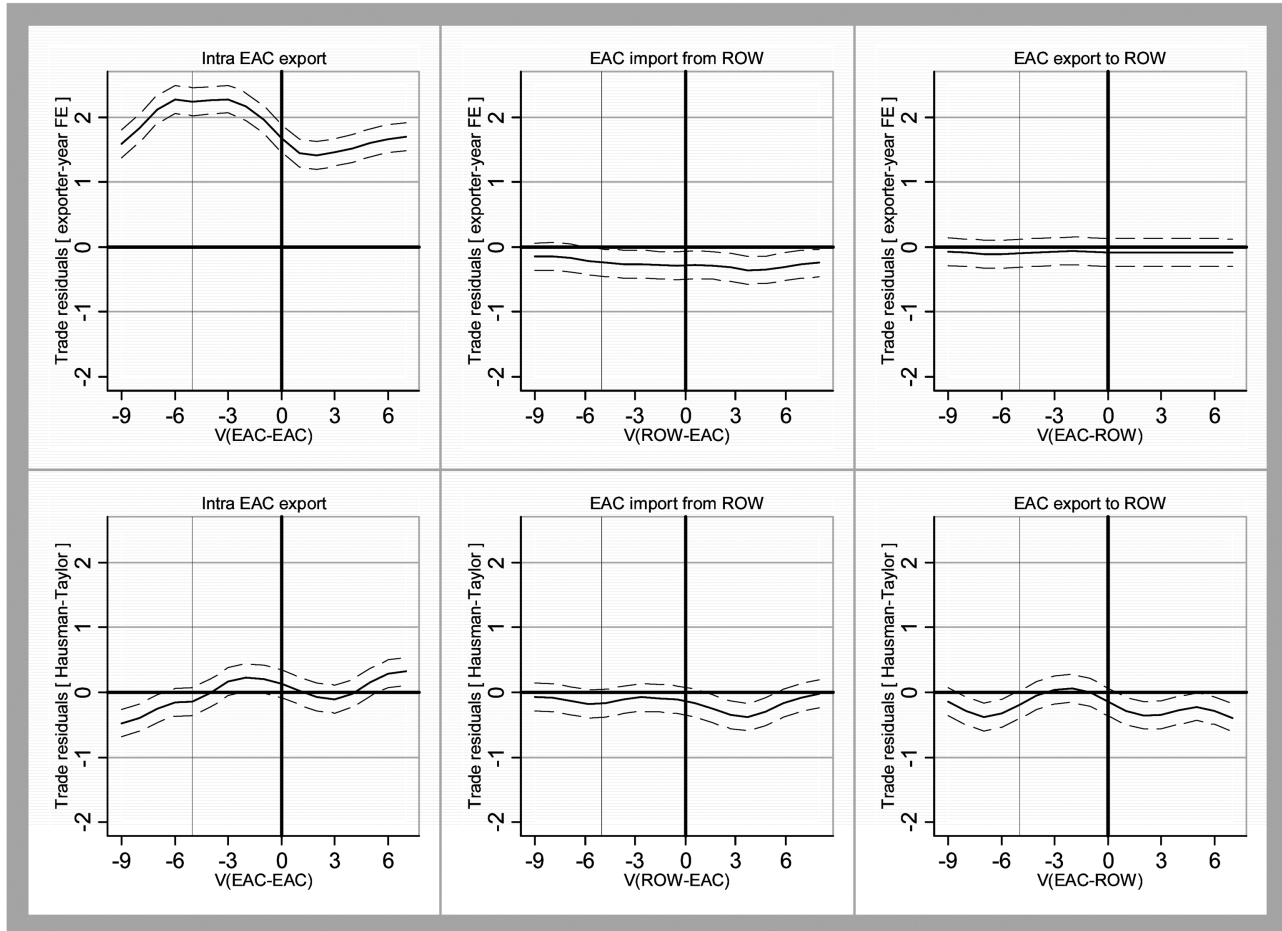

SACU Estimated Trade Impact

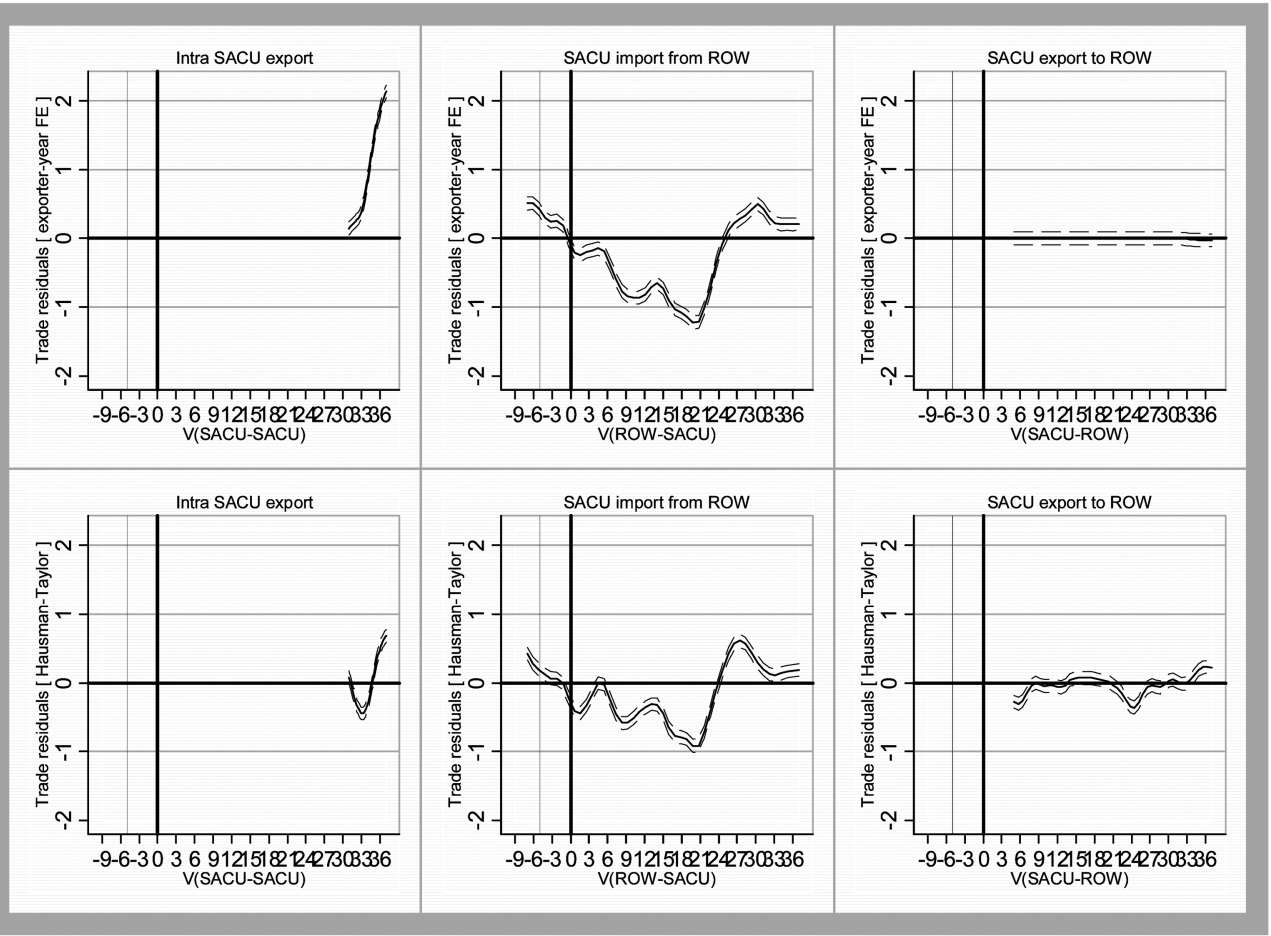


WAEMU Estimated Trade Impact
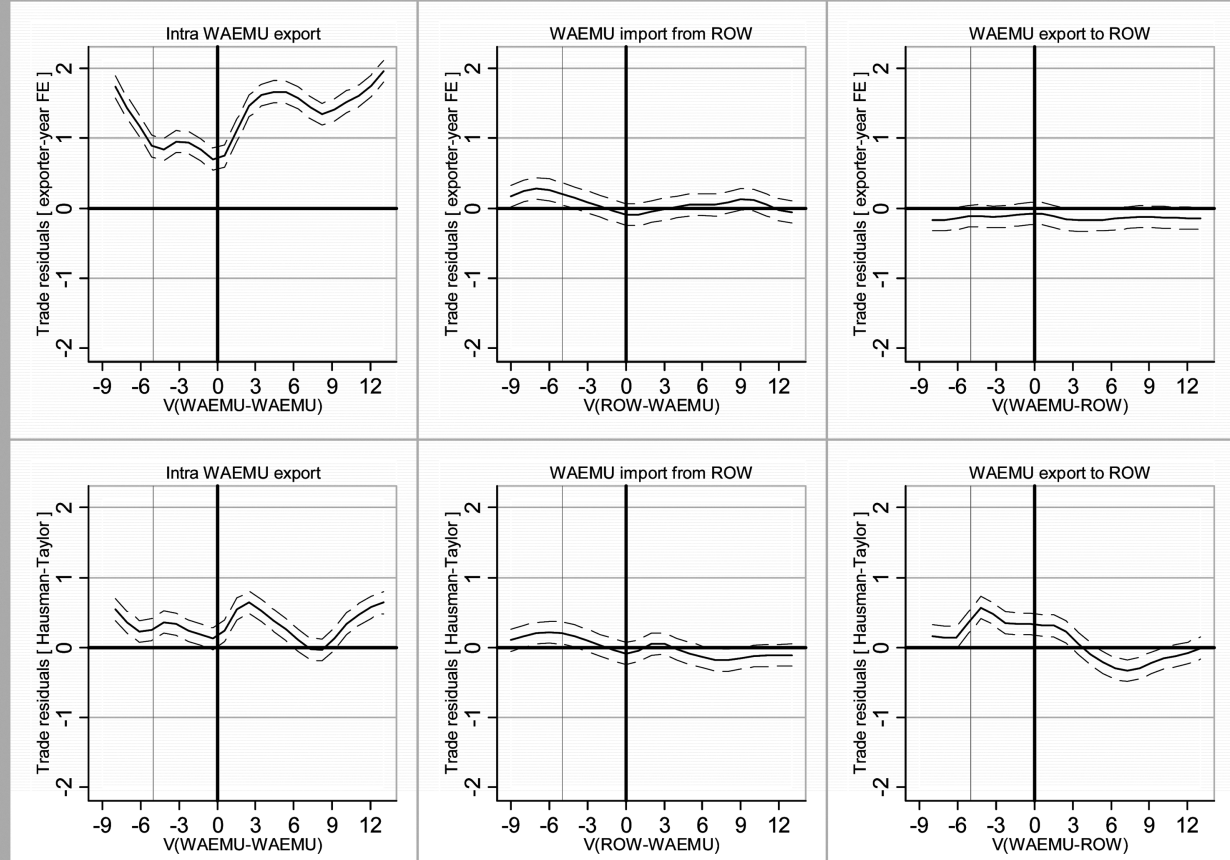

\section{ArFTA Estimated Trade Impact}

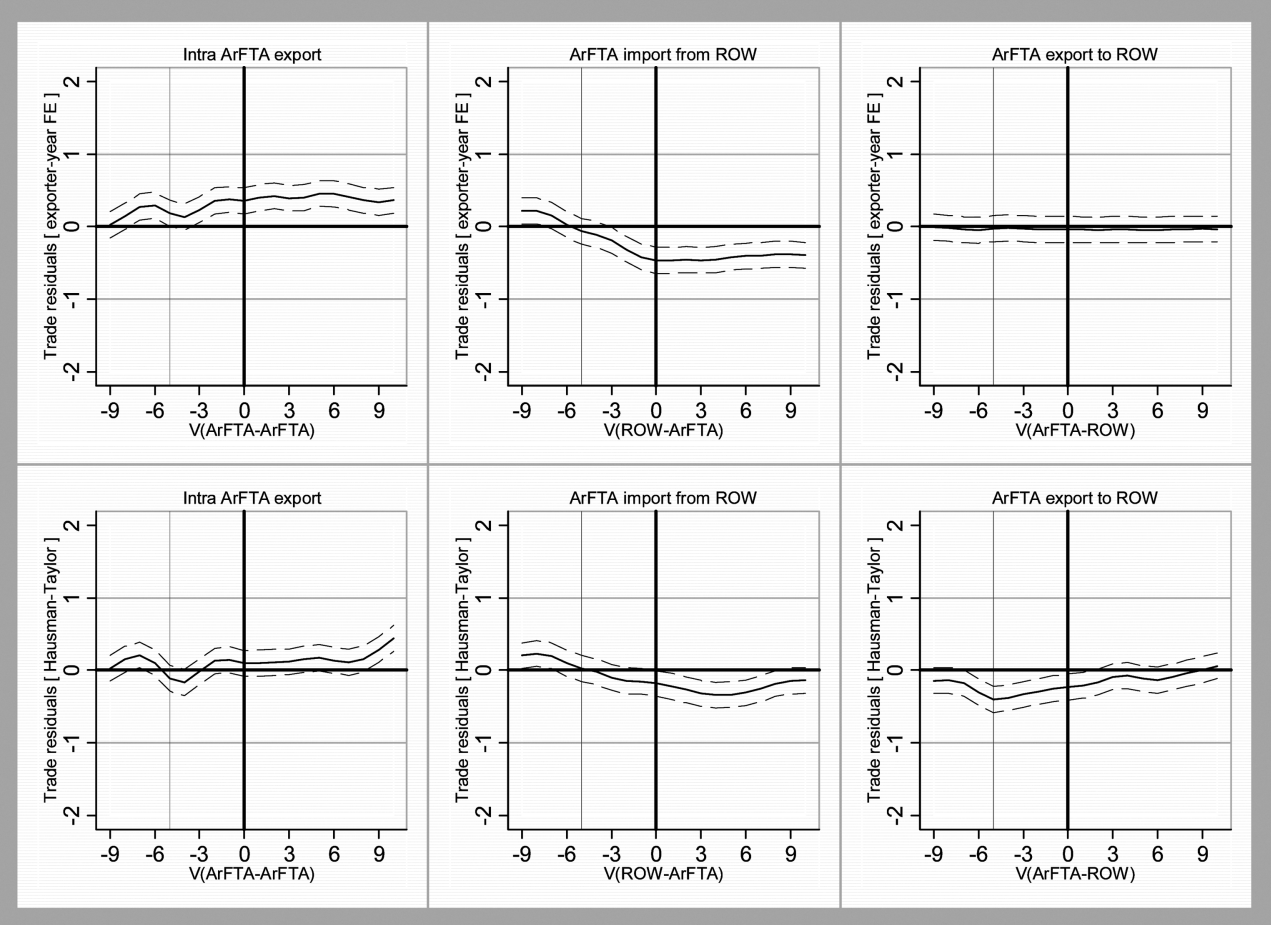


GCC Estimated Trade Impact
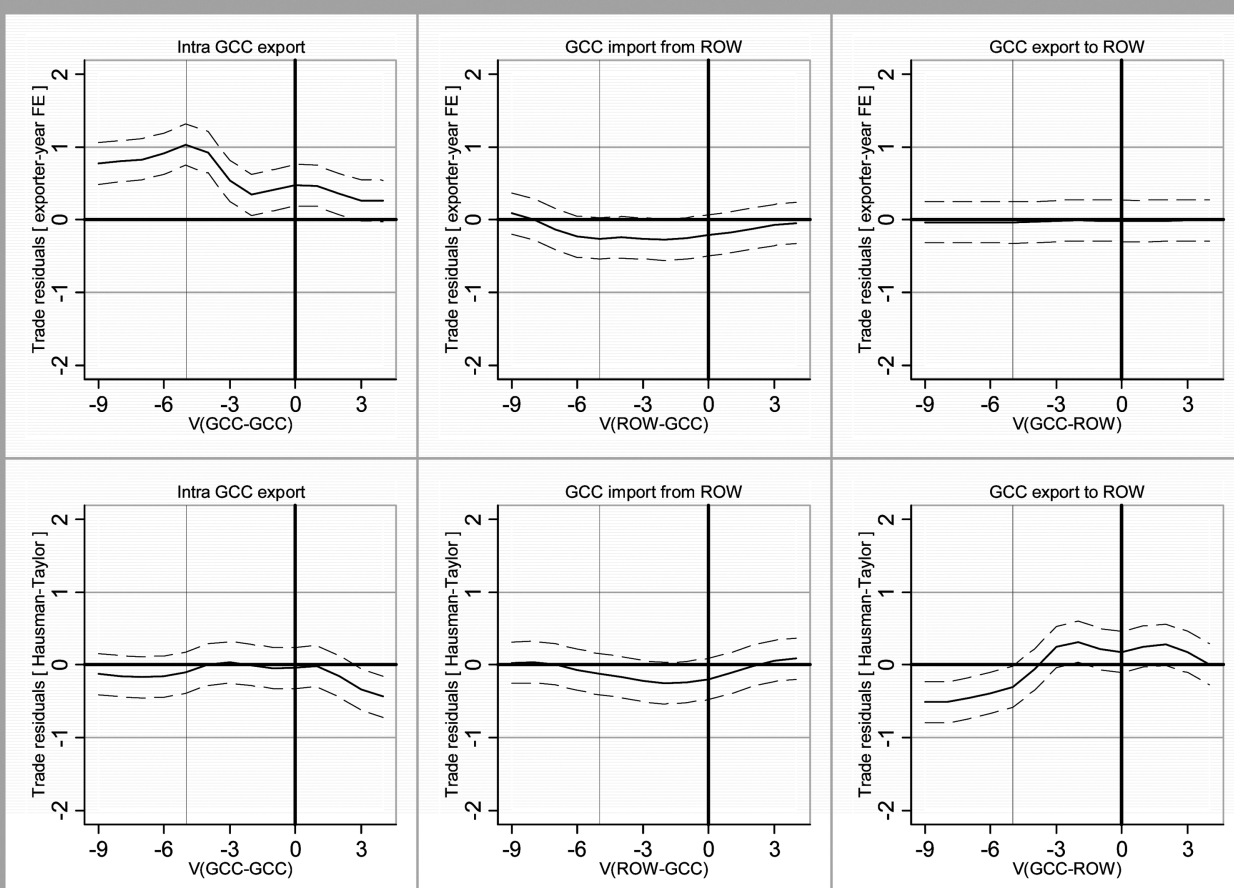

AMU Estimated Trade Impact
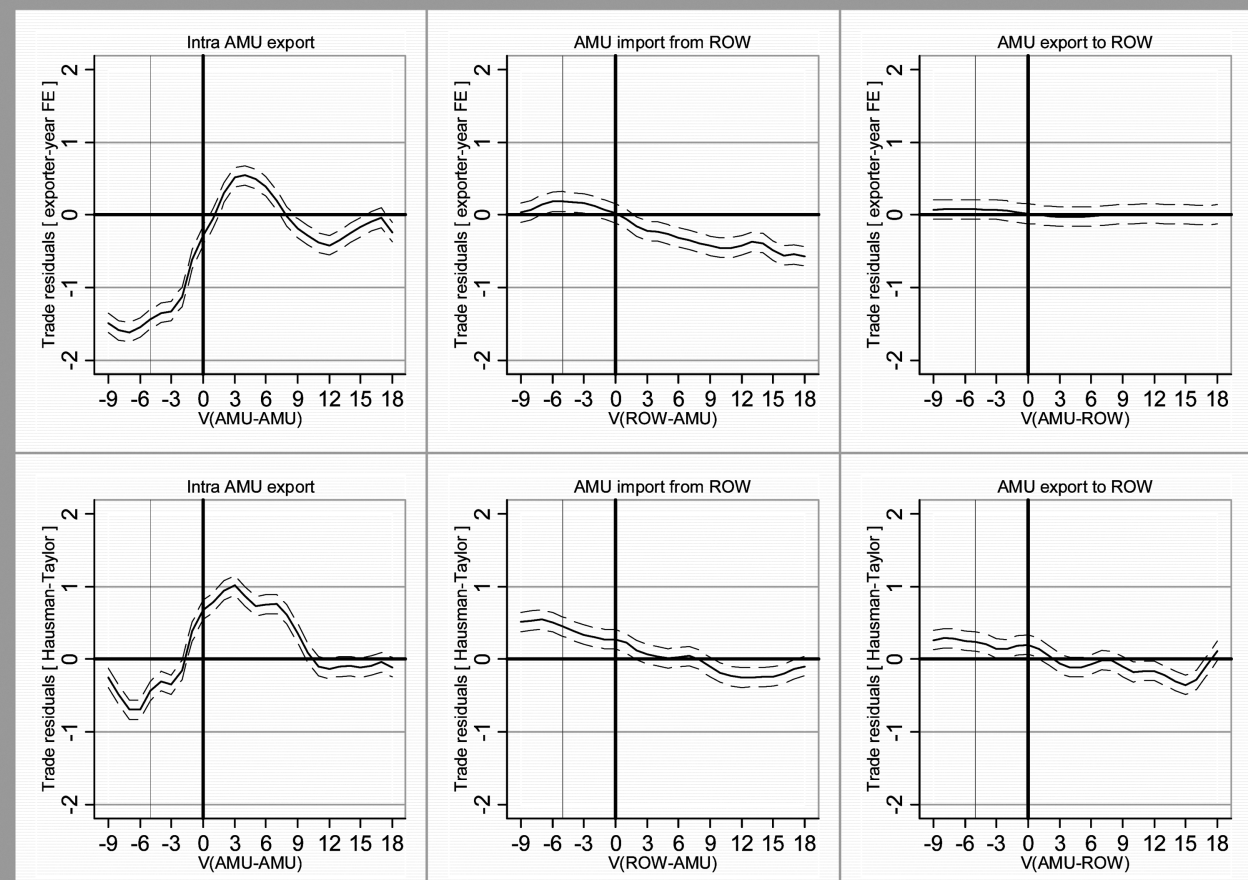
EU Estimated Trade Impact

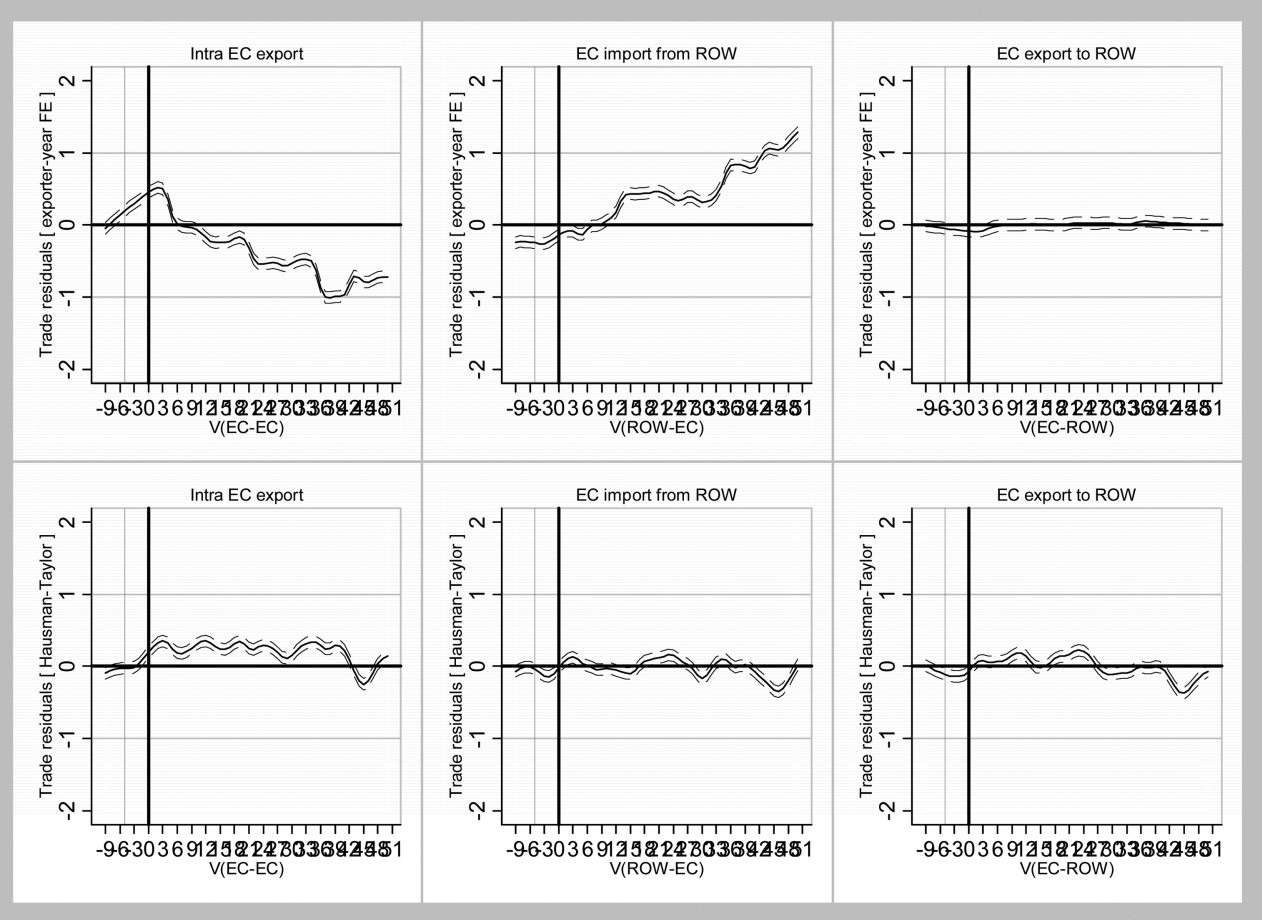

CIS Estimated Trade Impact

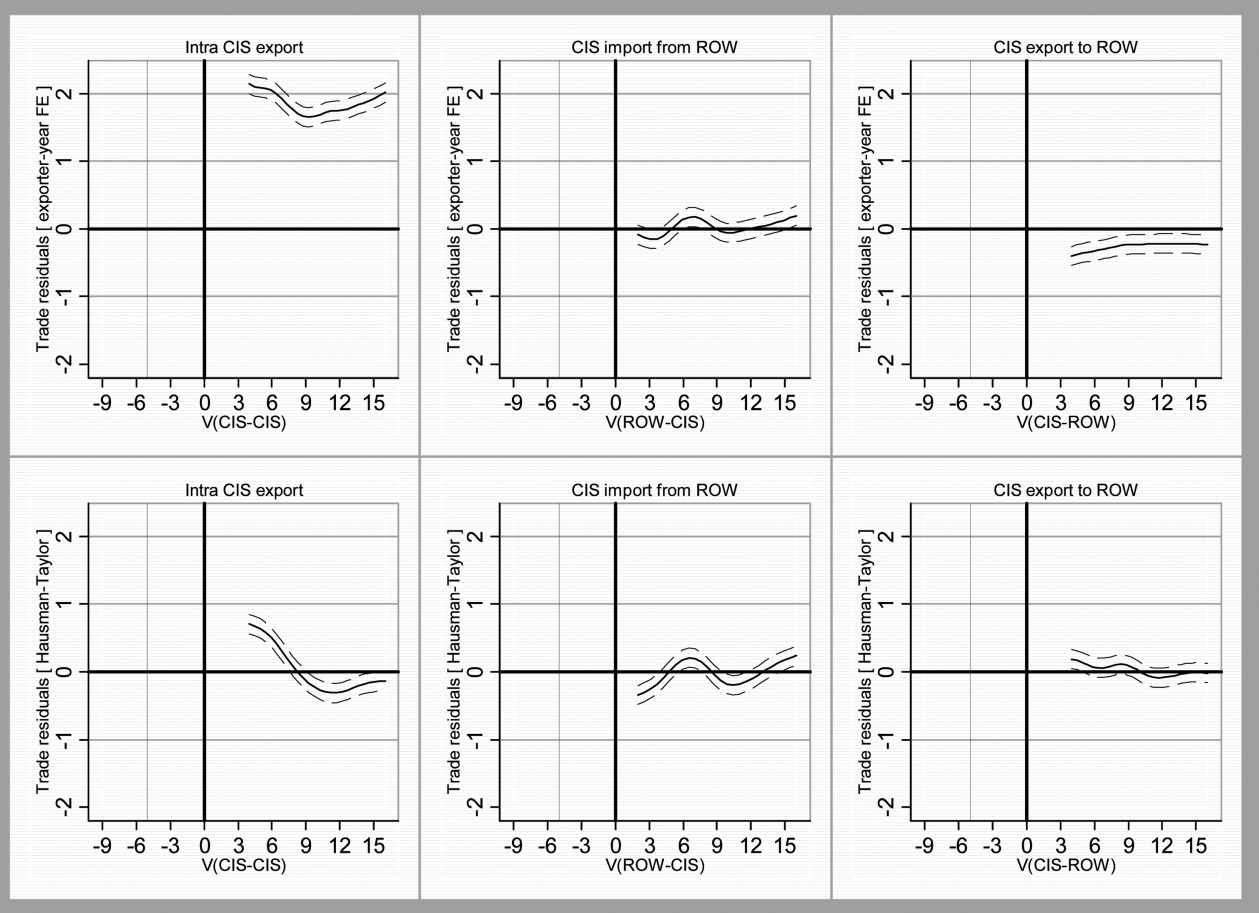


EEU Estimated Trade Impact

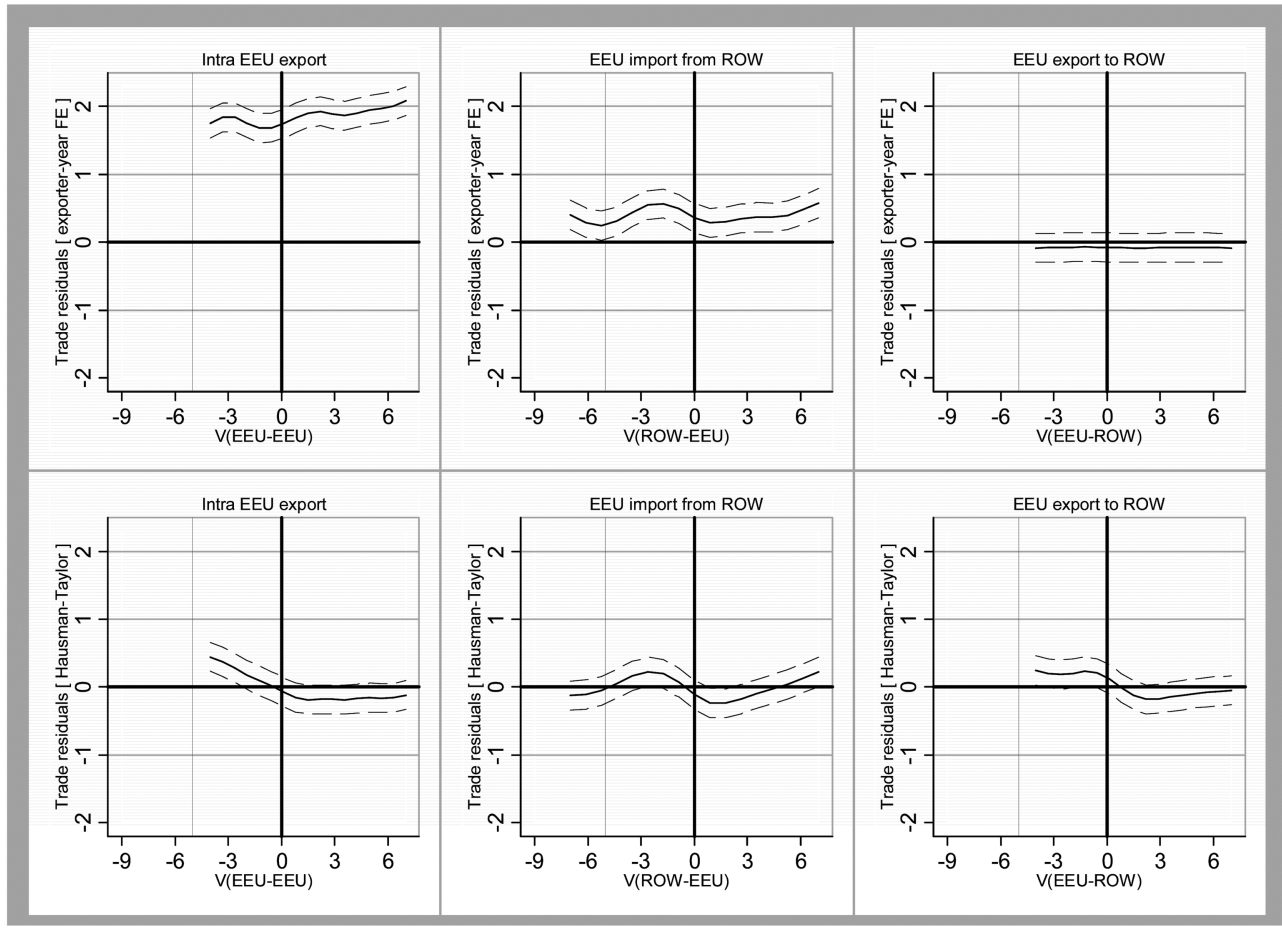

\section{References}

Aitken, N.(1973), "The Effect of the EEC and EFTA on European Trade: a Temporal Cross-Section Analysis", American Economic Review, 63, pp. 881-892.

Anderson, J. E., van Wincoop, E.(2003), "Gravity with Gravitas: a Solution to the Border Puzzle", American Economic Review, 93, pp. 170-192.

Baier, S. L., Bergstrand, J. H.(2002), "On the Endogeneity of International Trade Flows and Free Trade Agreements", American Economic Association Annual Meeting.

Baier, S. L., Bergstrand, J. H., Vidal, E.(2007), "Free Trade Agreements in the Americas: are the Trade Effects Larger than Anticipated?", World Economy, 30(9), pp. 1347-77.

Bierens, H. J.(1994), Topics in Advanced Econometrics, Cambridge University Press.

Baldwin, R., Taglioni, D.(2006), "Gravity for Dummies and Dummies for Gravity Equations", NBER working papers No. 12516.

Carrere, C.(2006), "Revisiting the Effects of Regional Trade Agreements on Trade Flows with Proper Specification of the Gravity Model", European Economic Review, 50, pp. 223-247.

Cernat, L.(2001), "Assessing Regional Trade Arrangements: Are South-South RTAs More Trade Diverting?”, Global Economy Quarterly, 2(3), pp. 235-59.

Cheng, I. H., Wall, H. J.(2005), "Controlling for Heterogeneity in Gravity Model of Trade 
and Integration", The Federal Reserve Bank of St. Louis Review, 87(1), pp. 49-63.

Dee, ph., Gali, J.(2003), "The Trade and Investment Effect of Preferential Trade Arrangements", NBER Working Paper No. 10160, 2003.

Egger, P.(2000), "A Note on the Proper Econometric Specification of the Gravity Equation", Economics Letters, 66(1), p. 25-31.

Egger, P., Pfaffermayr, M.(2003), "The Proper Panel Econometric Specification of the Gravity Equation: a Three-Way Model with Bilateral Interaction Effects", Empirical Economics, 28(3), p. 571-80.

Elliot, R., Ikemoto, K.(2004), "AFTA and the Asian Crisis: Help or Hindrance to the ASEAN Intraregional Trade?", Asian Economic Journal, 18(1), p. 1-10.

Feenstra, R.(2004), Advanced International Trade: Theory and Evidence, Princeton, N.J.: Princeton University Press.

Freund, C. L., McLaren, J.(1999), "On the Dynamics of Trade Diversion: Evidence from Four Trade Blocs", International Finance Discussion Paper no. 637.

Ghosh, S., Yamarik, S.(2004), "Are Regional Trading Arrangements Trade Creating? An application of Extreme Extreme Bounds Annalysis", Journal of International Economics, 63(2), pp. 369-395.

Krueger, A.(1999), "Trade Creation and Trade Diversion under NAFTA", NBER Working Paper No. 7429.

Limao, N., Venables, A. J.(2001), "Infrastructure, Geographical Disadvantage, Transport Costs, and Trade", World Bank Economic Review, 15(3), pp. 451-79.

Martinez-Zarsoso, I., Nowak-Lehman, F.(2003), "Augmented Gravity Model: an Empirical Application to MERCOSUR-EU Trade Flows", Journal of applied economics, 6(2), pp. 291-316.

Matyas, L.(1997), "Proper Econometric Specification of the Gravity Model", The World Economy, 20, p. 363-368.

Matyas, L.(1998), "The Gravity Model: Some Econometric Considerations", The World Economy, 21(3), p. 397-401

Nijman, T., Verbeck, M.(1992), Incomplete Panels and Selection Bias, In: Matyas, L., Sevestre, P. (Eds), The Econometrics of Panel Data. Kluwer, Dordrecht, pp. 262-302.

Rose, A.(2003), "Does the WTO Make Trade More Stable?", NBER Working Paper No. 10207.

Schiff, M., Winters, A.(2003), Regional Integration and Development, World Bank and Oxford University Press.

Soloaga, I., Winters, A. L.(2000), "Regionalism in the Nineties: What Effect on Trade?", North American Journal of Economics and Finance, 12(1), pp. 1-29.

UNCTAD(2000), Globalization, Regionalism and Africa's Development Agenda. Geneva. 